\title{
Institutions, climate change, and the foundations of long- term policymaking
}

\author{
Jared Finnegan
}

April 2019

Centre for Climate Change Economics and Policy Working Paper No. 353

ISSN 2515-5709 (Online)

Grantham Research Institute on Climate Change and the Environment Working Paper No. 321

ISSN 2515-5717 (Online) 
The Centre for Climate Change Economics and Policy (CCCEP) was established by the University of Leeds and the London School of Economics and Political Science in 2008 to advance public and private action on climate change through innovative, rigorous research. The Centre is funded by the UK Economic and Social Research Council. Its third phase started in October 2018 with seven projects:

1. Low-carbon, climate-resilient cities

2. Sustainable infrastructure finance

3. Low-carbon industrial strategies in challenging contexts

4. Integrating climate and development policies for 'climate compatible development'

5. Competitiveness in the low-carbon economy

6. Incentives for behaviour change

7. Climate information for adaptation

More information about CCCEP is available at www.cccep.ac.uk

The Grantham Research Institute on Climate Change and the Environment was established by the London School of Economics and Political Science in 2008 to bring together international expertise on economics, finance, geography, the environment, international development and political economy to create a world-leading centre for policy-relevant research and training. The Institute is funded by the Grantham Foundation for the Protection of the Environment and a number of other sources. It has six research themes:

1. Sustainable development

2. Finance, investment and insurance

3. Changing behaviours

4. Growth and innovation

5. Policy design and evaluation

6. Governance and legislation

More information about the Grantham Research Institute is available at www.Ise.ac.uk/Granthamlnstitute

\section{Suggested citation:}

Finnegan J (2019) Institutions, climate change, and the foundations of long-term policymaking. Centre for Climate Change Economics and Policy Working Paper 353/Grantham Research Institute on Climate Change and the Environment Working Paper 321. London: London School of Economics and Political Science

This working paper is intended to stimulate discussion within the research community and among users of research, and its content may have been submitted for publication in academic journals. It has been reviewed by at least one internal referee before publication. The views expressed in this paper represent those of the authors and do not necessarily represent those of the host institutions or funders. 


\title{
Institutions, climate change, and the foundations of long-term policymaking*
}

\author{
Jared J. Finnegan ${ }^{+}$ \\ April 2019
}

\begin{abstract}
Many policy problems require taking costly action today for future benefits. Do institutions structure the ability of governments to address long-term challenges? Examining the case of climate change, this paper argues yes. It focuses on the way that two institutions - electoral rules and interest group intermediation - drive variation in climate policies across the high-income democracies by structuring the political conditions needed for them to occur. Proportional electoral rules increase electoral safety, allowing politicians to impose short-term costs on constituents. Institutionalized relationships between industry and the state enable governments to compensate losers, defusing organized opposition to policy change. Moreover, their joint presence generates powerful institutional complementarities that push countries onto distinct varieties of decarbonization. Tests using new data on shadow carbon prices provide empirical support for the arguments. This analysis is the first to provide comprehensive theoretical arguments that link institutions to the distributional politics of long-term climate change policymaking. By doing so it illuminates causal mechanisms that should structure policy responses to a more general set of long-term challenges.
\end{abstract}

Keywords: Climate change, long-term policy, institutions, comparative political economy

\footnotetext{
* For their very helpful feedback and suggestions, I am grateful to Julius Andersson, Catherine Boone, Sam Fankhauser, Roger Fouquet, Fergus Green, Robert Keohane, Tobias Kruse, David Soskice, Kai Spiekermann, David Vogel, and Joachim Wehner, as well as audiences at the 2018 APSA Annual Conference, Fourth Annual Conference on Environmental Politics and Governance, 2018 MPSA Annual Conference, 2018 PSA Annual Conference, 2017 ECPR General Conference, 2017 and 208 SASE Annual Conference, 2016 ECPR Summer School on Environmental Politics and Policy, Grantham Research Institute on Climate Change and the Environment, and LSE Political Economy and Public Policy Workshop. Thank you to the Grantham Foundation for the Protection of the Environment through the Grantham Research Institute on Climate Change and the Environment and from the UK's Economic and Social Research Council (ESRC) through the Centre for Climate Change Economics and Policy for funding this research.

${ }^{+}$London School of Economics and Political Science and Grantham Research Institute on Climate Change and the Environment. Correspondence: j.finnegan@lse.ac.uk.
} 


\section{Introduction}

Long-term policy challenges - biodiversity loss, education and skills, infrastructure, and public debt - are everywhere, yet scholars are just beginning to examine their distinct political economy (Jacobs 2011, 2016). In the context of these types of issues, politics is not only about who gets what, but who gets what and when (Laswell 1936). Three features characterize long-term problems: they last at least one human generation, they exhibit considerable uncertainty given their long time horizons, and they entail problems of public goods, both at the stage of problem generation and policy response (Sprinz 2014, 127). Climate change is the quintessential long-term policy problem. If left unabated, its impacts will last for centuries; there is uncertainty regarding the exact timing, scale, and geographic distribution of future impacts; and it is caused by the twin market failures of public goods and externalities, while addressing the problem requires the collective provision of a stable climate - a global public good par excellence (Keohane and Victor 2016; Arrow 2007, 3). Why have some advanced capitalist democracies been more successful than others at addressing longterm problems like climate change? Outstandingly, political science has provided few answers to this substantively important question (Keohane 2015).

Recent theoretical work argues that addressing such problems is challenging for politicians in democracies for three reasons: the difficulty of imposing short-term costs on voters for benefits that will arrive in the future, uncertainty about whether future benefits will materialize, and overcoming opposition from cost-bearing organized groups (Jacobs 2011). Consequently, three necessary conditions are required for long-term "policy investments" to occur: electoral safety, expectations of long-term benefits, and capacity to overcome opposition from organized cost-bearing groups. While existing work has examined the role of cognitive biases, ideational factors, and veto points, we know less about how institutions systematically structure the necessary conditions for long-term policy investment (Jacobs 2011). Yet, we know from existing research, particularly in comparative political economy, that institutions play a major role in shaping policy outcomes across countries, including taxation, trade, social policy, corporate governance, and labour markets. ${ }^{1}$ I argue that they play a similar role in the case of long-term policy.

By examining the political economy of climate change mitigation policy, this paper gives an account of the institutional foundations of long-term policymaking. ${ }^{2}$ It focuses specifically on the way that two institutions - electoral rules and interest group intermediation - drive cross-

\footnotetext{
${ }^{1}$ For example, see Gourevitch and Shinn (2005); Hall and Soskice (2001); Katzenstein (1985); Martin and Swank (2012); Steinmo et al. (1992).

2 I use climate change mitigation policy, climate change policy, and climate policy interchangeably. What I am referring to are policies that aim to reduce greenhouse gas (GHG) emissions.
} 
national variation in long-term climate policy investments by structuring the political conditions needed for such investments to occur. I argue that proportional electoral (PR) rules increase electoral safety by decreasing clarity of responsibility and electoral competitiveness, which in turn enables governments to impose short-term costs on their constituents. Corporatist institutions for interest group intermediation facilitate bargaining between the government and powerful economic actors over compensation for the losers of policy change, which helps governments overcome industry opposition. Lastly, I theorize how the joint presence of both institutions generates powerful complementarities that reinforce their independent effects. PR rules decrease risks associated with shifting costs toward voters, which opens up critical room to maneuver when negotiating compensation with cost-bearing groups. Moreover, these types of complementarities generate distinct varieties of decarbonization that drive differences in climate policy investments across the high-income democracies. On the one hand are negotiated political economies with consensusbased democratic institutions and coordinated market economies. On the other are competitive political economies with majoritarian democracies and liberal market economies. Each institutional environment entails a different political logic vis-à-vis climate change policy. Lastly, the arguments predict that negotiated political economies are better able to address a wider range of long-term policy challenges.

I test the arguments using new cross-national data on climate policy stringency. A consistent picture emerges. Between countries, and within them over time, stringency is higher when electoral rules are more proportional and levels of concertation are high. Furthermore, the joint presence of these institutions is similarly associated with high levels of policy investment. To better identify their effect, I examine the influence of institutions on the distribution of policy costs between producers and consumers. As theorized, I find a distinct distributive profile underlying climate policy investment. PR rules and concertation are associated with much higher costs for consumers relative to producers, and this bargain drives higher overall policy stringency. Conversely, plurality rules and interest group pluralism are associated with a more equal distribution of costs between the two groups, which results in comparatively lower levels of overall investment. This finding is important because it highlights how institutions structure the distributive politics of climate change policy, and by doing so, drive variation in governments' ability to do respond to the problem.

This paper makes a number of contributions. First, it provides a theoretical account of the micro-foundations that link institutions to long-term climate policy. We know surprisingly little, theoretically or empirically, about the political determinants of variation in climate policy stringency across the high-income democracies (Bernauer 2013; Keohane 2015; Purdon 2015). This 
paper seeks to contribute to filling this large gap by examining the role of political institutions an area that has so far received scant attention (Lipscy 2018; Mildenberger 2018). Moreover, it seeks to develop theory about how the joint presence of certain institutions creates complementarities that push countries onto distinct climate policy pathways and generate varieties of decarbonization. Secondly, the paper contributes to the growing literature on the politics of long-term policymaking (Jacobs 2011, 2016). By focusing specifically on the role of institutions it tests and extends existing theory. By focusing on climate change it extends empirical research into new critical cases of long-term policy problems. Lastly, the paper contributes to the climate policy debate by elucidating the ways that institutions structure opportunities for and constraints on climate policy adoption. Doing so helps to shed light on why some countries take strong action to address climate change, while others do not. Information that can enable the design of climate policy instruments that better take account of country-specific institutional settings, rather than relying one-size-fitsall prescriptions.

\section{The puzzle of climate change policy}

Effectively responding to climate change poses many well-known challenges for governments (Bernauer 2013; Hovi et al. 2009; Levin et al. 2012). However, despite the obstacles politicians have acted to address climate change and these actions occurred before and after countries joined international agreements. Indeed, serious efforts to adopt climate change policy have been attempted in all high-income democracies over the past three decades. The puzzle is that the stringency of policy portfolios varies considerably across countries (Figure 1). What explains this variation? Why have some countries done much to address climate change while others have done little? A puzzling question considering that climate change arrived on the policy scene at virtually the same time for all high-income democracies - by the mid-1980s. Moreover, by 1992 each had signed the United Nations Framework Convention on Climate Change (UNFCCC), which committed them all to an identical domestic emissions reduction goal. ${ }^{3}$ This of course includes countries that are now considered climate laggards, such as the US. ${ }^{4}$ Yet from this relatively common starting point, countries quickly diverged along radically different policy trajectories. Why?

\footnotetext{
${ }^{3}$ Each country committed to reducing its emissions to 1990 levels by 2000. See Article 4 Section 2a of UN (1992). These goals were not just international, but backed up in each of the countries by national goals and strategies.

${ }^{4}$ For example, on Earth Day in 1993, then President Bill Clinton publicly affirmed the US's commitment to reduce its emissions in line with the international goal (Clinton 1993).
} 
Figure 1. Climate change policy stringency across countries ${ }^{5}$

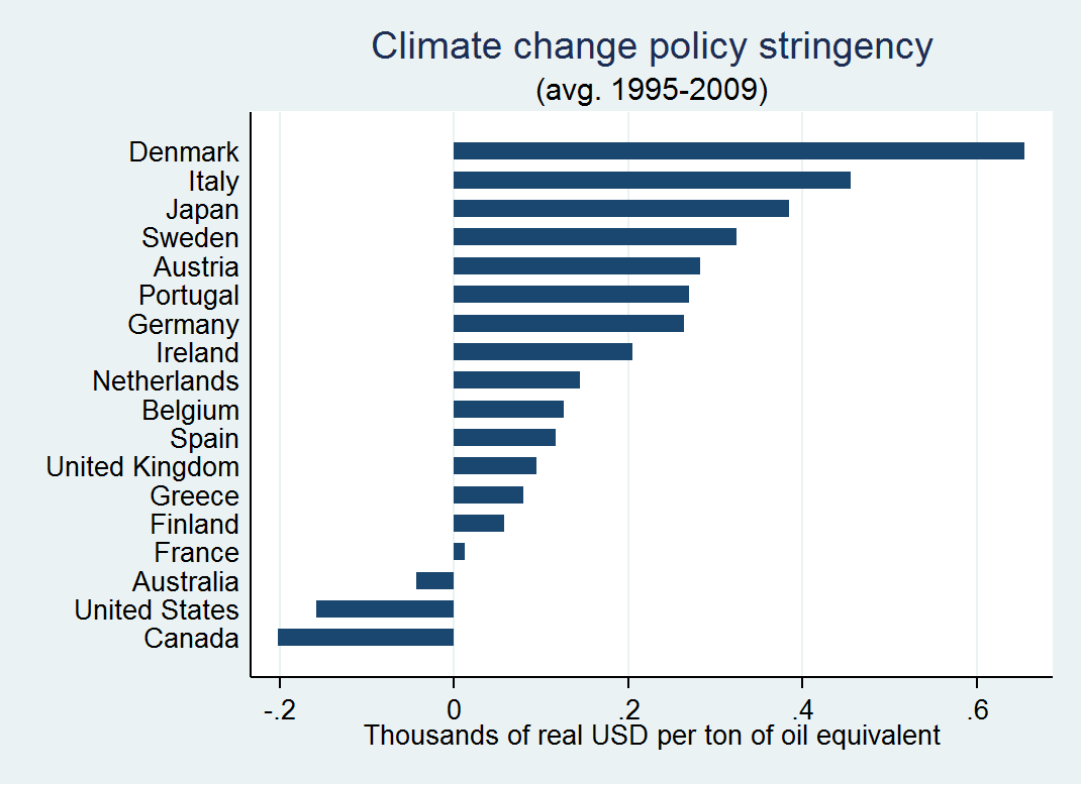

Surprisingly, political science has provided few answers (Keohane 2015). Existing research has explained why addressing climate change has been difficult for governments, however the domestic factors that drive cross-national variation in policy adoption are still under-researched (Bernauer 2013; Purdon 2015). A marked lack of theory development also characterizes the subfield in general and many previous studies in particular (Cao et al. 2014). Surprisingly, only a few scholars have attempted to provide a general theory of climate policy adoption (Harrison 2015; Hughes and Urpelainen 2015). Perhaps for this reason, cross-national empirical studies have identified multiple variables that are correlated with climate policy, but a framework for how they might fit together is still lacking. ${ }^{6}$ This paper seeks to fill this large theoretical gap by examining the role of political institutions. Institutions constitute the basis of democratic and capitalist diversity across the high-income countries and structure a range of policy outcomes (e.g., Iversen and Soskice 2006; Martin and Swank 2012; Rogowski and Kayser 2002). The case of climate change should be no different, yet only recently have a small handful of studies explored their effects in this policy area (Lipscy 2018; Meckling and Nahm 2018; Mildenberger 2018). ${ }^{7}$ Moreover, we are still missing an account of climate policy adoption that takes seriously the institutional complementarities that

\footnotetext{
5 This is a measure of the average "shadow" carbon price across the economy from Althammer and Hille (2016). It captures the extent to which government policy increases or decreases carbon-based energy prices relative to an undistorted market price. See Section 5.1 for further details.

${ }^{6}$ See Fankhauser et al. (2015a, 2015b); Fredriksson and Neumayer (2013, 2014); Harrison and Sundstrom (2010); Madden (2014); Rafaty (2018); Tobin (2017).

${ }^{7}$ However, they have received more attention in studies of non-climate related environmental policies (e.g., Crepaz 1995; Jahn 2016; Scruggs 2003).
} 
underpin distinct patterns of democracy and varieties of capitalism. Lastly, we lack well-identified, robust large-N empirical evidence. Part of the reason has been the availability of data. This paper helps to address this issue by utilizing new data on climate policy stringency and interest group intermediation.

\section{The politics of long-term climate policy investment: A theoretical framework}

Climate change politics is distributive politics. In aggregate, government policies to reduce greenhouse gas (GHG) emissions benefit society as a whole. However, like other types of long-term economic policy, the distribution of costs and benefits are not uniform across social actors or through time (Jacobs 2011). As a result, climate policy involves distributive conflict along two axes (see Figure 2). The first is intertemporal (vertical axis in Figure 2). Climate policy extracts economic resources today and invests them in the production of a slowly emerging consumption good - a stable climate that is hospitable to human life. ${ }^{8}$ Distributive conflict arises as governments decide whether and how much of today's resources to invest. The level of climate policy investment can be conceptualized as the overall stringency of a given country's policy portfolio and measured by the level of short-term costs imposed on economic actors. The second dimension of distributive conflict is cross-sectional (horizontal axis in Figure 2). The short-term costs of long-term climate policy investments must be borne by economic actors today. Distributive conflict arises as governments decide which actors are to pay. For parsimony, the two primary actors can be conceptualized generally as producers (i.e., industry and their workers) and consumers (i.e., voters). The basic choice for governments is therefore whether to impose short-term costs directly on producers, consumers, or some combination of the two. ${ }^{9}$ For example, when implementing a carbon tax politicians can decide to apply the same rate to both groups, impose a higher rate for industry (e.g., the UK Climate Change Levy), or impose a higher rate for consumers (e.g., the Swedish carbon tax until 2018).

Climate change policy offers a unique distributional profile that sets it apart from other long-term policy investments. Most importantly, it is not technically feasible to redistribute the

\footnotetext{
${ }^{8}$ Today's resources are invested via policies that, for example: increase prices for carbon-intensive goods and services (e.g., carbon taxes and emissions trading schemes), subsidize low-carbon technology (e.g., feed-in-tariffs for renewable energy), compel firms to invest in cleaner production process (e.g., performance standards), and increase government R\&D expenditure.

${ }^{9}$ I am concerned with the political decision of distributing the direct costs of climate policy. I therefore leave aside a detailed discussion of the secondary question of cost incidence, which will depend on the price elasticity of supply and demand.
} 
Figure 2. Possible distributional profiles of climate policy investment ${ }^{10}$

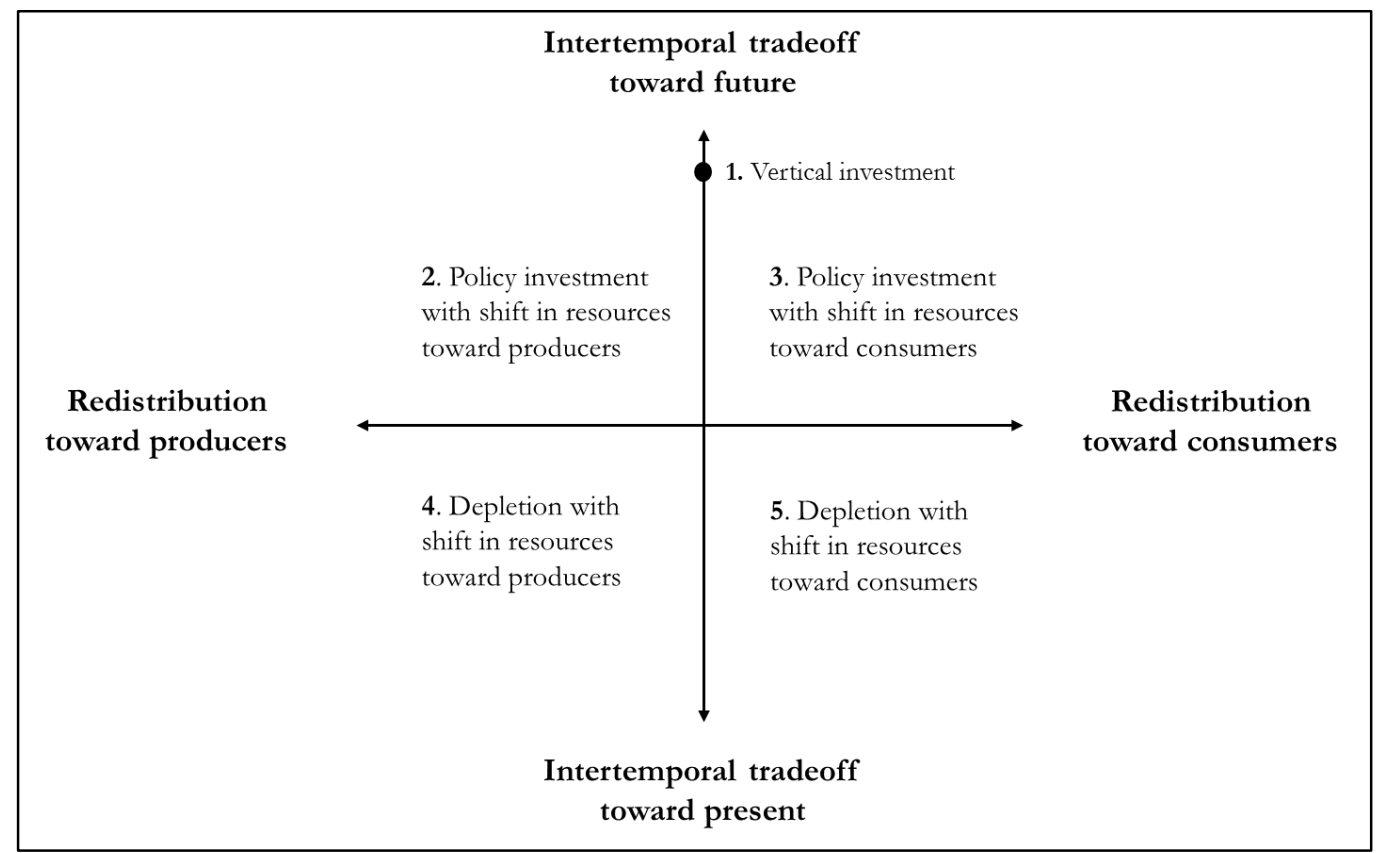

future benefits of a stable climate (or the costs of an unstable one). ${ }^{11}$ These are global public goods (or bads) and will therefore be enjoyed equally by all social actors. This contrasts it from long-term policies, such as pensions policy, which offer social actors the possibility of redistributing the future costs and benefits of policy change to one group over another (Jacobs 2011). This matters because it shapes the distributional strategies that actors pursue, particularly cost-bearing organized groups. Without the possibility for such groups to fully capture the future benefits of policy, the political economy of climate change should be driven primarily by cross-sectional distributive conflict. That is, by the opportunities for and constraints on cross-sectional distribution today between producers and consumers of the short-term costs of long-term climate policy.

Governments wanting to make long-term climate policy investments therefore need to be successful in pursuing a distributive strategy that charts a stable and credible allocation of shortterm costs between industry and voters. There are risks on both fronts. Increased costs for voters may produce electoral backlash, which removes the governing party(ies). Increased costs for industry may cause them to counter-mobilize and block policy change. An emerging body of research on long-term policymaking provides insight on the political economy of overcoming such risks (Jacobs 2011). ${ }^{12}$ First, politicians' willingness to impose short-term costs on voters should

\footnotetext{
${ }^{10}$ Adapted from (Jacobs 2011).

${ }^{11}$ This is a simplification in the interest of parsimony. To be sure, the relative gains from climate policy will not be the same across all actors or over time.

${ }^{12}$ See also González-Ricoy and Gosseries (2016); Jacobs (2016); Jacobs and Matthews (2012, 2017); Jacobs and Weaver (2015); Lindvall (2017); Mackenzie (2016).
} 
depend on the extent to which they enjoy some level of electoral safety, which can insulate them against potential electoral backlash. Secondly, in the case of producers, governments require the capacity to overcome opposition from organized groups that will bear the short-term costs of climate policy investment. In the next section I theorize about how institutions should systematically structure these necessary conditions, and by doing so, drive variation in climate policy investment across countries.

\section{Institutions and long-term climate policy investment}

\subsection{Electoral rules and electoral safety}

In order to adopt climate policy investments politicians must have a relatively low risk of losing office for imposing its associated short-term costs on their constituents (Finnegan 2018; Garrett 1993; Jacobs 2011; Tvinnereim 2013). The key assumption is that voters have high discount rates, which tilt their preferences against bearing high short-term costs for benefits that arrive in the future. A variety of studies support this assumption. ${ }^{13}$

Institutions should systematically structure electoral safety across countries, particularly electoral rules. This should occur via two causal mechanisms. First, proportional (PR) electoral rules tend to decrease electoral competitiveness - the expected probability that the governing party (or largest party in the governing coalition) loses it seats plurality in the next election (Kayser and Lindstädt 2015). They do so by decreasing seats-votes elasticities, or the marginal expected gains in a party's seat share in the national legislature for a given increase in the party's national vote total (Rogowski and Kayser 2002). Lower electoral competition decreases the political risk of directly imposing costs on voters (Finnegan 2018). Indeed, for this reason PR rules are associated with higher consumer prices (Chang et al., 2010; Rogowski and Kayser, 2002). Secondly, PR rules tend to decrease clarity of responsibility, making it more difficult for voters to assign responsibility for policies they dislike and sanction politicians accordingly (Powell and Whitten 1993). One way they do this is via multiparty governments. PR tends to generate coalition governments, while plurality rules usually result in single-party ones. All else equal, voters should find it easier to punish single-party governments (Hobolt et al. 2013; Powell and Whitten 1993). Moreover, even if a party loses significant votes it can remain in government under PR as a result of coalition bargaining.

\footnotetext{
${ }^{13}$ On individual discount rates see Frederick et al. (2002) and Jacobs and Matthews (2012 and 2017). On the "low-cost hypothesis" in environmental psychology, which proposes that individuals' support for environmental policy decreases as the personal costs of the policy rise, see Drews and Bergh $(2015,5)$.
} 
The overall result is that PR rules should better insulate politicians from marginal changes in the electoral preferences of unhappy consumers, which should reduce the political risk of imposing short-term costs on them. Conversely, under plurality rules, politicians from two major parties face highly competitive contests over the median voter, which generates strong incentives to pay close attention to these voters' short-term preferences for low prices, especially regarding emissionsintensive goods and services.

It is important to note that my arguments diverge from previous work regarding the relationship between electoral rules and climate policy. These studies have emphasized a partisan effect, whereby PR rules open up possibilities for green parties to win parliamentary seats and influence policymaking (Harrison and Sundstrom 2010; LaChappelle 2011). My arguments on the other hand emphasize electoral incentives - a more fundamental causal mechanism that should affect political decision-making regardless of partisanship. Furthermore, they are consistent with a recent turn in climate politics research, which builds on long-standing work in comparative political economy about the relationship between electoral rules and consumer prices. For example, Lipscy (2018) shows how, in the case of energy efficiency policy, electoral rules systematically structure electoral insulation, which shapes the ability of politicians to impose diffuse costs on household energy consumers.

\subsection{Interest group intermediation and organized opposition}

Even if politicians experience electoral safety, they still require the capacity to overcome opposition from organized groups that will bear the short-term costs of policy investments (Jacobs 2011, 58-63). Indeed, one key obstacle to climate policy that is often hypothesized in the literature is the ability of organized opponents, especially emissions-intensive industries such oil, gas, and coalfired utilities, to block policy change (e.g., Hughes and Urpelainen, 2015). To be sure, a number of factors will influence the ability of governments to overcome opposition from these groups and enact long-term policy investments into law; for example, institutional veto points and the centralization of policymaking (Jacobs 2011). Here I explore another: institutions that structure interactions between cost-bearing organized groups and the government, particularly corporatism.

In its stylized form, corporatism is a coordinated and compromise-oriented arrangement for structuring interactions between firms and between industry and government (Crouch 1993; Iversen and Soskice 2009; Schmitter 1974). It includes a number of dimensions. The focus here is on concertation, or the extent to which institutions grant relatively few encompassing, hierarchal, and monopolistic peak associations privileged access to pre-legislative government policymaking 
via long-standing linkages to political parties, legislative committees, and/or the public administration. Conceptually, concertation constitutes institutionalized political exchange between privileged interest groups and the state (Crouch 1993; Öberg et al. 2011). Each actor controls resources that the other desires. Governments control legislation, public expenditure, and the ability to privilege selected organizations. Organized groups control the opinions of their members, which influences public support for government policy and votes for the governing coalition. Concertation involves industry exchanging political support for the government's agenda in return for influence over the shape and rate of policy change. Industry participates in such exchanges because firms have a material interest in maintaining a cooperative regulatory environment. Deviations could unsettle existing policy compromises across a range of other issues important to industry.

For governments wanting to take action on climate change, concertation should increase the likelihood of successful long-term policy investment because it increases the likelihood of credible compensation for cost-bearing organized groups. When undertaking significant reforms, especially those that entail major distributive conflict such as climate policy, governments have two general options for dealing with powerful cost-bearing groups: compensate them or ignore them (Lindvall, 2017). In the case of climate policy, compensation can take a variety of forms: for example, select industries can be wholly or partially exempted from compliance costs or they can receive refunds and subsidies. The challenge for governments is that compensation involves its own set of political costs. It may make the policy less effective (dilution costs), be expensive to administer (deadweight costs), take too much time and energy to negotiate (transaction costs), or make other important political actors, especially voters, react negatively (audience costs) (Lindvall, 2017, Ch.3).

Crucially, concertation should influence these costs. First, deliberation between the government and a limited number of highly organized peak associations, with the authority to decide on behalf of their members and bind them to the terms of any future agreement, should reduce the transaction costs of negotiating a stable and credible long-term distributive bargain. Moreover, corporatist networks are based on long-standing and frequent face-to-face interaction between industry, trade unions, and government, which promotes trust - a key ingredient for further reducing transaction costs (Lindvall 2017, Ch.3). Second, negotiations typically take place in private and outside of the legislative process (Martin, 2013, 130). Indeed, the threat of legislative action, which would exclude interest group preferences, is often used as a penalty for inaction. Holding negotiations in secret can reduce audience costs (Lindvall 2017, ch.3). Lastly, corporatist networks are well-established in many democracies and have long been used to negotiate compensation for policy change (e.g., Martin 2014). As a result, compensation in the case of climate policy should 
require little in the way of additional administrative resources and therefore few deadweight costs. Lastly, compensation agreements are credible. They are usually supported by all political parties, reducing the likelihood that they will be upended by a future government. At the same time, individual firms and unions are bound to them via their representative peak associations. For both sides, deviating from the agreement jeopardizes future cooperation.

Compensating, rather than ignoring, cost-bearing groups should lead to higher long-run climate policy investment (and therefore lower dilution costs) via three related causal pathways. The first channel regards the sequencing of costs for industry. By defusing organized opposition, compensation makes it more likely that governments have early success in enacting climate policy into law. To be sure, these early investments are likely to impose few costs on carbon-intensive industry. However, through ongoing negotiations we should expect incremental increases in stringency over time that gradually increase costs for polluters. Indeed, more stringent climate policy often becomes possible only after the adoption of early, moderate, and politically feasible policy options (Kelsey 2018; Meckling et al. 2015).

Second is electoral politics. Remember that the government exchanges compensation for industry's support of their climate policy agenda. Powerful social actors have the resources and capacity to shape public perceptions of government action on climate change. Eliciting their support means they should be less likely to mobilize public conflict. In particular, they should be less likely to attempt to influence voters' climate policy preferences by drawing attention to short-term policy costs. This works to reduce the political salience of such costs. Under these conditions, government should find it less risky to adopt policies that impose costs on voters, which in turn increases the level of overall policy investment.

Last is policy reversal. As mentioned, agreements regarding climate policy investments between government and cost-bearing groups will be long term in nature and agreed to by all political parties and powerful economic interests. Moreover, cooperative veto points are diffuse, offering all sides a say over future policy change (Birchfield and Crepaz 1998). Changes will therefore tend to be incremental and negotiated, rather than radical or unilaterally imposed by a new government after an election. The likelihood of wholesale policy reversal is low, which increases long-run levels of policy investment.

Conversely, when governments lack institutionalized bargaining with cost-bearing organized groups, as is the case in majoritarian democracies with interest group pluralism, the political costs of negotiating compensation are likely to be high. Additionally, under these conditions governments will tend to be more insulated from such groups. First, groups lack institutionalized access to pre-legislative policymaking and will therefore find it difficult to exploit institutional veto 
points. Second, a governing party(ies) wishing to adopt stringent climate policy will tend not to rely on political support from such groups, almost by definition. As a result, these governments are more likely to ignore cost-bearing groups, all else equal.

This strategy should make governments more likely to impose short-term cost on industry. For this reason, radical, disruptive policy change is more likely, since high costs can be imposed on carbon polluters shut out of policy design negotiations (Mildenberger 2018). However, counterintuitively, this distributive strategy is likely to result in comparatively lower long run climate policy investment. First, it will tend to antagonize powerful economic actors. Lacking pre-legislative influence over policy design, especially regarding compensation, these firms will tend to view any climate policy investment as a threat, and thus have few reasons to support it. Instead, in an effort to exercise influence during the legislative phase, they face strong incentives to countermobilize, expanding the scope of distributive conflict and turning climate change into "noisy politics" (Culpepper 2010). They are likely to employ two strategies: (1) intensely lobby individual legislators in an attempt to win particularistic policy concessions or block policy change outright and (2) influence voters' climate policy preferences via mass information campaigns that increase the salience of short-term costs or sew doubts about climate science. As a result, climate change is likely to become highly politicized and the focus of intense public conflict. With the costs of climate policy investments made highly salient for voters, governments will find it difficult to impose even moderate costs on them for fear of electoral backlash. Secondly, and perhaps more importantly, ignoring cost-bearing groups does not make them go away. Once their political allies regain control of government they are likely to reverse course and repeal climate policy. The overall result should be a boom-and-bust policy cycle and intense public conflict. It should also reduce policy credibility as social actors begin to anticipate policy reversal.

These arguments offer a causal mechanism - compensation - which links interest group intermediation to long-term climate policy investments. By doing so, they theoretically situate findings from manifold country case studies that highlight the role of peak associations and corporatist bargaining in climate policymaking in: Scandinavia (Daugbjerg and Pedersen 2004; Kasa 2000; Midttun and Hagen 1997; Mildenberger 2018), Austria (Brand and Pawloff, 2014; Hermann et al., 2016; Tobin, 2017), the Netherlands (Hermann et al., 2016; Kemp 2010) and Germany (Hatch 1995; Meckling and Nahm 2018; Renn and Marshall 2016). They also explain why governments in countries like Denmark, Germany, the Netherlands, and Switzerland have been more successful 
at negotiating voluntary climate change-related agreements with industry compared to the U.S. and France (Baranzini and Thalmann 2004; Delmas and Terlaak 2002)..$^{14}$

Previous cross-national studies have described a relationship between a general conception of corporatism and climate policy (e.g., Tobin 2017). However, my arguments go further by providing a clear causal pathway that links one feature of corporatism - concertation - to higher levels of climate policy investment via compensation for cost-bearing groups. They are most closely related to recent work by Mildenberger (2018). Though they diverge in important ways. Mildenberger argues that corporatism stabilizes the political influence of carbon-intensive policy losers, which inhibits disruptive, non-incremental policy change and locks in low policy stringency. That is, corporatism is associated with excessive policy dilution costs. This view implicitly assumes that costs for producers are the measure of policy stringency. While these costs are surely important, I contend that the overall stringency of a country's policy portfolio crucially depends on the distribution of short-term costs between both producers and consumers. Eliciting the political support of industry via compensation can enable governments to increase costs for voters and, over time, incrementally increase costs for industry. As a result, we should expect comparatively higher levels of long-run climate policy investment.

\subsection{Institutional complementarities}

I have argued that both electoral rules and concertation have independent effects on long-term climate policy investment. Here I theorize how their joint presence generates powerful complementarities that reinforce these effects. Across the high-income democracies, electoral rules tend to go together with forms of interest group intermediation. Indeed, they co-evolved for important historical reasons and constitute the institutional basis of democratic and capitalist diversity (Hall and Soskice 2001; Cusack et al. 2007; Lijphart 2012; Iversen and Soskice 2009). In "consensus" democracies with coordinated market economies, PR rules co-occur with concertation. Conversely, in "majoritarian" democracies with liberal market economies, first-past-the-post electoral rules co-occur with interest group pluralism.

The complementarity between PR rules and corporatism should simultaneously reduce the political risks of imposing costs on consumers and producers. Because PR rules increase electoral safety, they decrease risks associated with shifting costs toward voters, giving governments the

\footnotetext{
14 They are also consistent with studies that demonstrate a positive relationship between corporatism and environmental performance (Jahn 2016; Scruggs 2003).
} 
option to do so. This flexibility opens up critical room to maneuver when negotiating compensation with cost-bearing groups. By shifting short-term costs toward consumers, governments can offer policy exemptions to industry and still retain the overall integrity of the policy investment. In this way, the institutional complementary between electoral rules and corporatism can prevent excessive dilution costs. At the same time, offering compensation to powerful cost-bearing organized groups reduces the likelihood that distributive conflict enters the public arena or that industry increases the salience of short-term costs for voters, which should make it easier for governments to impose such costs on them. To be sure, this type of policy investment, which distributes higher costs toward voters, is less stringent than one that imposes similarly high costs on both voters and industry. However, I have tried to show that, given its political risks, that type of distributive bargain is rarely feasible for governments, at least initially.

The complementarity between plurality electoral rules and interest group pluralism has a different logic. First-past-the-post rules decrease electoral safety and thereby increase the political risk of imposing costs on voters, which will tend to take this distributive channel off the table. For governments serious about climate policy investment, the only other available channel is to impose short-term costs on industry. But because they lack institutionalized pre-legislative bargaining with cost-bearing groups and parties in these governments will rarely rely on the political support on carbon-intensive firms, government will tend to ignore policy losers. Moreover, this strategy prevents excessive dilution costs. Since governments will be reticent to impose costs on voters, they have to impose real costs on industry or the policy investment will have little stringency. Additionally, by imposing costs on industry, especially intermediaries such as electricity and fuel suppliers, the link between consumers' short-term losses and the policy that produced them can be obscured, hiding the costs of policy investments and decreasing electoral accountability. However, as described above, the risk is that, in an effort to influence policy design from the outside in, industry counter-mobilizes and expands the scope of conflict. The fundamental problem is that a strategy of ignoring losers, which will be politically attractive in this institutional setting, does not reconcile distributive conflict, but instead amplifies and expands it. The overall result should be a deeply adversarial and conflict-ridden policy process that produces lower levels of long-run climate policy investment.

These arguments predict that consensus democracies are more likely to implement and sustain climate policy. Climate policy is a type of long-term policy investment and institutions in consensus democracies are more likely to provide governments the necessary conditions for making such investments. Indeed, in making the case that consensus democracy is "kinder and gentler", Lijphart $(2012$, 291) himself provides evidence that consensus democracy is associated with 
higher environmental performance. ${ }^{15}$ Moreover, a number of studies have hinted that these types of political economies are better able to address a wide range of long-term policy challenges (Birchfield and Crepaz 1998; Crepaz 1996; Lindvall 2017, Ch 5). Here I offer a theoretical explanation as to why.

\subsection{Observable implications}

The arguments above offer a number of observable implications regarding the effects of institutions:

- Electoral rules:

- Proportional electoral rules are associated with higher overall levels of climate policy investment

- Proportional electoral rules are associated with higher short-term policy costs for consumers relative to producers

- Interest group intermediation:

- Concertation is associated with higher overall levels of climate policy investment

○ Concertation is associated with higher short-term costs for consumers and producers

- Institutional complementarities:

○ Levels of climate policy investment will be highest (lowest) in countries where PR rules and concertation are jointly present (absent)

\section{Empirical analysis}

\subsection{Research design}

I am interested in explaining why some advanced capitalist democracies do more than others to address long-term problems like climate change. I therefore employ a comparative, cross-national research design that examines between-country differences in climate policy investments, as well as within-country differences over time when data allows. The first step is to collect a valid crossnational measure of long-term climate policy investment. Conceptually, climate policy investment is the amount of today's resources that are devoted to the provision of a stable future climate. This

15 Though additional studies have found mixed results (Bernauer and Böhmelt 2013; Ozymy and Rey 2013; Poloni-Staudinger 2008). 
"amount" can be measured by policy stringency, or the short-term costs that policy imposes on economic actors. More stringent policies are more costly and therefore represent a larger investment of today's resources. To measure policy stringency I utilize new data from Althammer and Hille (2016) who estimate the "shadow price" of carbon-based energy for 33 sectors (all primary, secondary, and tertiary sectors) between 1995 and 2009. ${ }^{16}$ Government policy drives a wedge $\lambda_{E}$ between an economic actor's shadow price $Z_{E}$ for an additional input of carbon-intensive energy $E$ (energy from electricity, coal, natural gas, diesel, gasoline, heavy fuel oil, and light fuel oil) and the energy source's undistorted world market price $p_{E}$, so that:

$$
Z_{E}=p_{E}+\lambda_{E}
$$

The wedge $\lambda_{E}$ is then a measure of all government policy that changes the price of carbonintensive energy inputs. A positive wedge indicates that policy raises the price above its market price, while a negative wedge indicates that policy subsidizes usage of the energy source. The benefit of this approach is that it captures all policies that affect the price of carbon-intensive energy inputs (e.g., taxes, subsidies, regulations, and cap-and-trade schemes) and summarizes the stringency of a country's climate policy portfolio across the economy regardless of its multidimensionality. Because I am first interested in a single economy-wide measure of policy investment I calculate the average wedge $\lambda_{E}$ across all sectors $s$ in country $i$ in year $t$. Throughout the paper I refer to this measure as "overall climate policy investment".

A further benefit of the data is that it is disaggregated by sector. Most important for my purposes are the separate stringency estimates for industrial and service sectors. Because the industrial data relies on industrial energy prices and services data on household prices, I use each as a proxy for the distinct short-term costs imposed on industry ("costs for producers") and voters ("costs for consumers"), respectively. ${ }^{17}$ Lastly, I calculate the difference between them to measure the distribution of costs between consumers and producers ("difference in costs"). When this measure equals zero, producers and consumers pay equal amounts. However, higher values indicate higher costs for consumers relative to producers. Conceptually, it provides a measure for the level of compensation enjoyed by producers.

To my knowledge this paper is the first to use this data. A key limitation of previous quantitative cross-national studies is the measurement of climate policy, whether as a count of climate-

\footnotetext{
16 Thank you to Erik Hille for making the data available to me.

${ }^{17}$ For a full list of sectors see Appendix A1.
} 
Figure 3. Climate change policy investment across countries (avg.1995-2009)
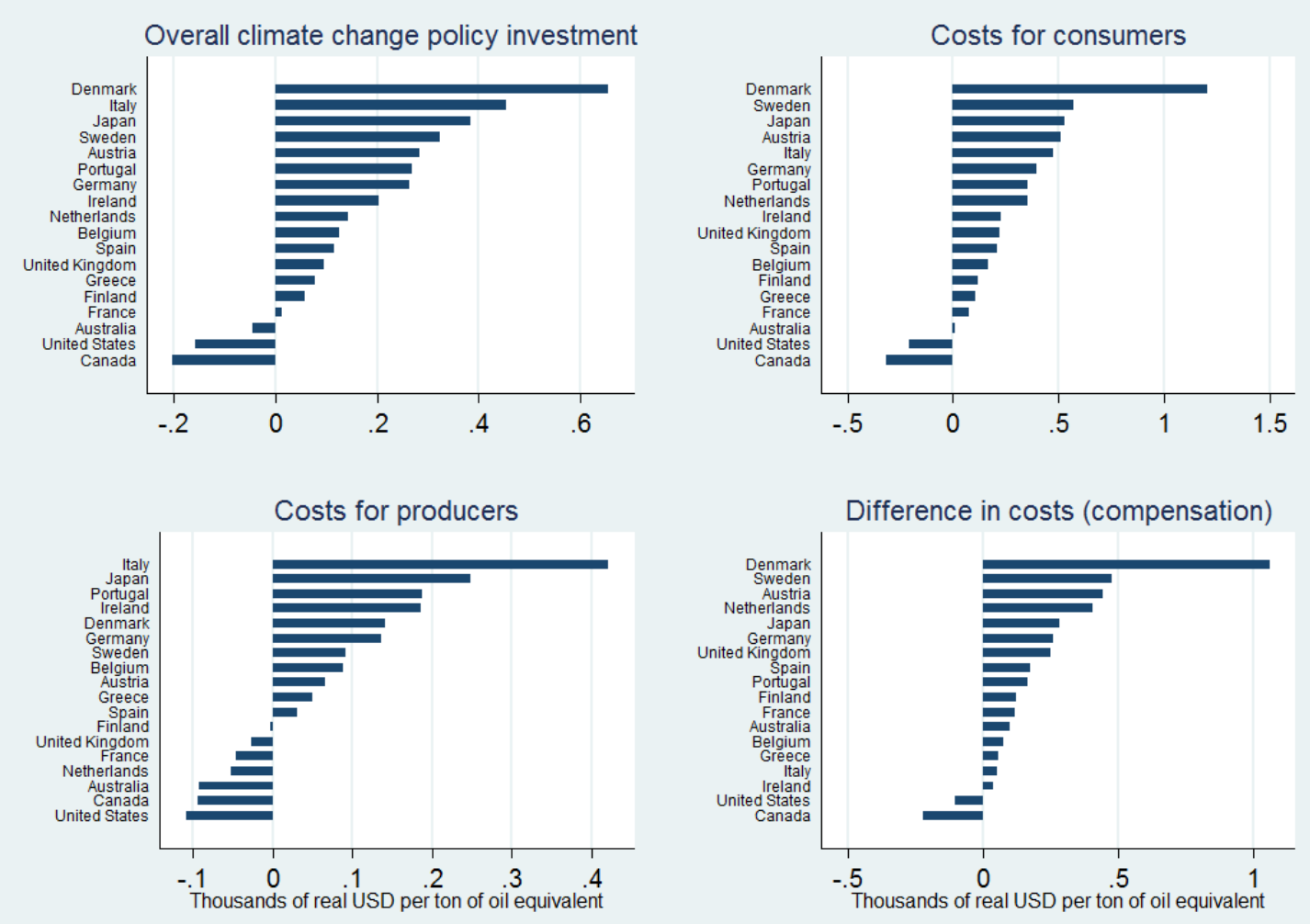

related laws (Fankhauser et al. 2015b), a subjective score of policy stringency (Madden 2014; Fredriksson and Neumayer 2013), or a measure of general environmental policy stringency (Rafaty 2018). By relying on objective and comparable sector-level energy price data, the shadow price approach overcomes these previous limitations. To date, it is the most detailed measure available of climate policy stringency. Though one drawback is that it does not capture policies that have no effect on the price of carbon-intensive energy inputs, such as voluntary measures undertaken by firms. Nor does it measure policies that target greenhouse gases apart from carbon dioxide.

Figure 3 shows the average level of overall climate policy investment across countries between 1995 and 2009 (top left quadrant). Government policy in almost all countries increases the price of carbon-based energy above its market price. However, the amount to which it does so varies considerably, from an average of 655 USD per ton of oil equivalent (toe) in Denmark to 13 USD in France. In Australia, Canada, and the US, government policy acts as a subsidy. That is, rather than being an investment (an intertemporal tradeoff toward the future), policy generates an intertemporal tradeoff toward the present, depleting the future resource of a stable climate. Examining the distribution of costs between consumers and producers reveals that almost all countries distribute some costs toward consumers, except Canada and the US where again policy subsidizes the use of carbon-based energy (top right quadrant). The case of producers is mixed. In 
some countries policy imposes costs on industry, while in others it acts as a subsidy (bottom left quadrant). Lastly, we see that in almost all countries consumers pay more of the short-term costs of climate policy investment, except for Canada and US where producers pay more than consumers (bottom right quadrant).

\subsection{Electoral rules and climate policy investment}

To test the relationship between electoral rules and climate policy investment, I plot electoral proportionality against overall policy stringency. To measure the proportionality of electoral rules I use data from Lijphart (2012) on average long-run electoral disproportionality from 1981-2010. We see a negative relationship, as expected (Figure 4). Countries with more (less) proportional rules have higher (lower) levels of overall climate policy investment. To better identify the effect of electoral rules, let us examine their impact on the distribution of costs between consumers and producers. My arguments predict that PR rules are associated with higher costs for consumers, but not necessarily producers. Similarly, as rules become more disproportional politicians should distribute short-term costs more evenly between the two groups. In the language of Jacobs (2011), electoral rules should influence the extent to which policy investments are vertical (Option 1 in Figure 2) or generate simultaneous cross-sectional and intertemporal shifts in resources (Options 2 and 3). Plotting electoral rules separately against costs for producers and consumers we find evidence for these arguments (Figure 5). Electoral rules have a differential impact on costs for consumers versus producers. When rules are more proportional voters are predicted to pay more than industry. However, this difference shrinks as rules become more disproportional. Indeed, at levels of disproportionality over ten, there is no statistical difference between costs for consumers and producers.

Electoral disproportionality is only substantively meaningful across countries, which limits possibilities for more sophisticated analysis. However, I test the robustness of the identified relationships using OLS models to regress averages for the four measures of climate policy on average electoral disproportionality and a set of controls: EU membership, institutional veto points, "greenness" of governments' policy preferences, domestic fossil fuel production, and GDP growth (described further below). Even with a sample size of 18, the estimates confirm the findings from the scatter plots. ${ }^{18}$

${ }^{18}$ See Appendix A3. 
Figure 4. Electoral rules and climate policy investment (with 95\% CIs) (avg 1995-2009)

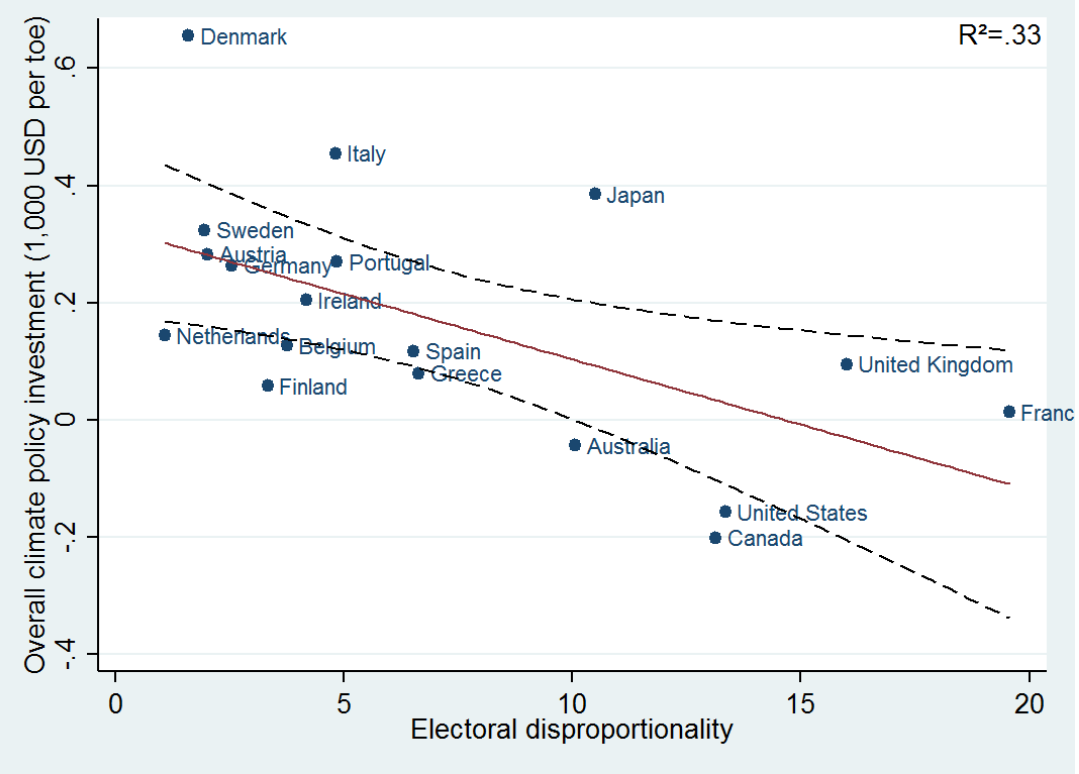

Figure 5. Electoral rules and distribution of costs between consumers and producers (with 95\% CIs) (avg 1995-2009)

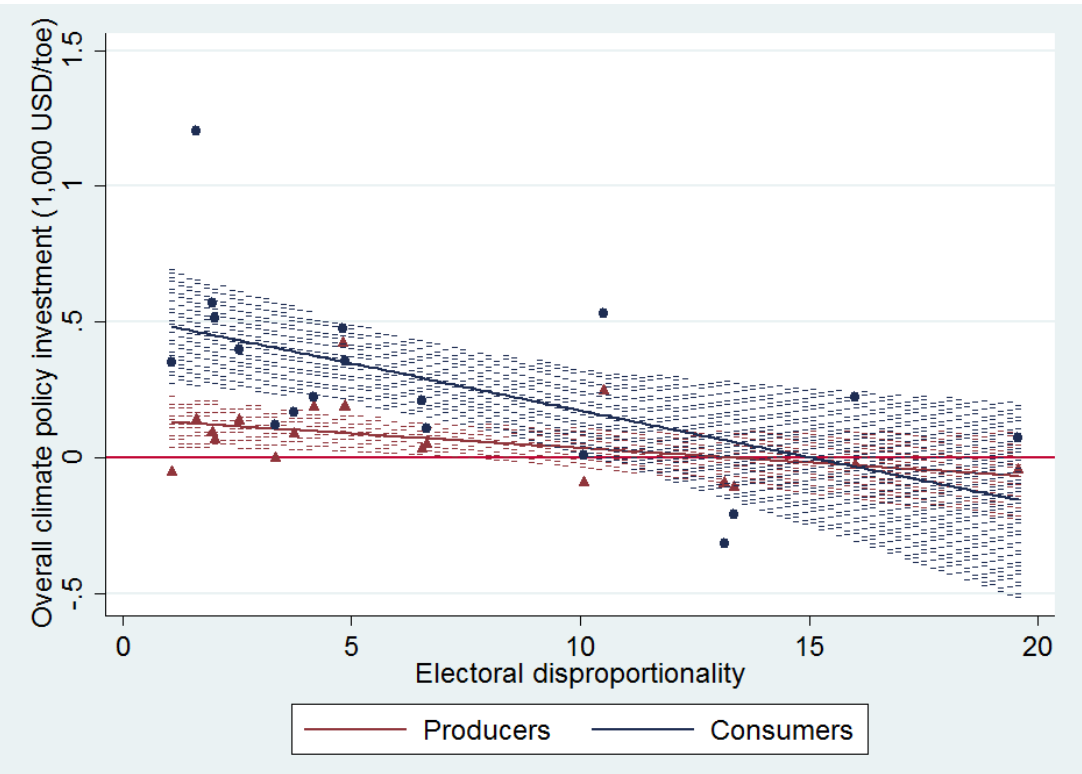

\subsection{Interest group intermediation and climate policy investment}

I turn next to testing arguments concerning the relationship between interest group intermediation and climate policy investment. To do so, I first collect data on the degree of concertation between the government and economic actors from Visser (2015). The variable ranges from 0-2 and measures the routine involvement of employers and labor unions in policymaking. Conceptually, 
it should provide a valid measure of the degree to which organized groups enjoy privileged access to climate policymaking - my primary variable of interest. Before using the data, I make one change. Visser (2015) codes Japan as zero for all years of the sample. This is due to the country's unique system of "corporatism without labor" (Lehmbruch 1984). However, a variety of case studies have shown the close relationship between highly organized industry associations and the government, especially the Ministry of Economy, Trade and Industry (METI) (e.g., Lipscy 2018; Mildenberger 2018). Because this is the phenomenon I am looking to measure, rather than whether employers and labor unions are routinely involved in policymaking, I recode Japan as two. ${ }^{19}$

I first plot the cross-national relationship between policy stringency and concertation (Figure 6). As expected, we observe a positive relationship. In countries where organized interests are routinely involved in policymaking, overall climate policy is more stringent. Unlike electoral rules, levels of concertation vary in substantively meaningful ways both between countries and within them over time, which enables more rigorous empirical analysis. ${ }^{20}$ To do so, I estimate a series of "between-within", or hybrid, regression models of the form (Bell and Jones 2015):

$$
y_{i t}=\beta_{0}+\beta_{1}\left(x_{i t}-\bar{x}_{i}\right)+\beta_{2} \bar{x}_{i}+\beta_{3} z_{i}+\left(u_{i}+e_{i t}\right)
$$

where $y_{i t}$ is the dependent variable, $x_{i t}$ is a series of time-variant independent variables measured at the occasion level (i.e., country-year), and $z_{i}$ is a series of time-invariant variables measured at the country level. $\beta_{1}$ is the within-unit effect (in my case, relying on variation within countries over time) and $\beta_{2}$ is the between-unit effect (relying on cross-sectional variation across countries) for each time-variant variable $x_{i t} . \beta_{3}$ is the between-country effect of each time-invariant variable $z_{i}$. The "random" part of the model is in brackets and consists of $u_{i}$, the higher-level error term for each country $i$, and $e_{i t}$, the occasion-level error term for each country $i$ in year $t$. I estimate the model within the random effects framework using the approach described by Schunck $(2013,68){ }^{21}$

The most likely confounder in my analysis is membership in the European Union (EU). The EU has been active in promoting climate change policy in its member states, especially after

\footnotetext{
${ }^{19}$ However, the results do not significantly change when Visser's (2015) coding is used.

${ }^{20}$ Concertation varies over time in 9 of 18 countries in the sample: Australia, Austria, France, Germany, Ireland, Italy, Portugal, Spain and Sweden. This should be kept in mind when interpreting the results. ${ }^{21}$ Random effects models are often criticized for not meeting their key identifying assumption that the residuals are independent of the covariates. Hybrid models overcome this issue (Bell and Jones 2015, 137). Because they fully account for both within and between effects, no additional variance is absorbed by the error terms $u_{i}$ and $e_{i t}$, so they cannot be correlated with the covariates.
} 
Figure 6. Concertation and climate policy investment (with 95\% CIs) (avg 1995-2009)

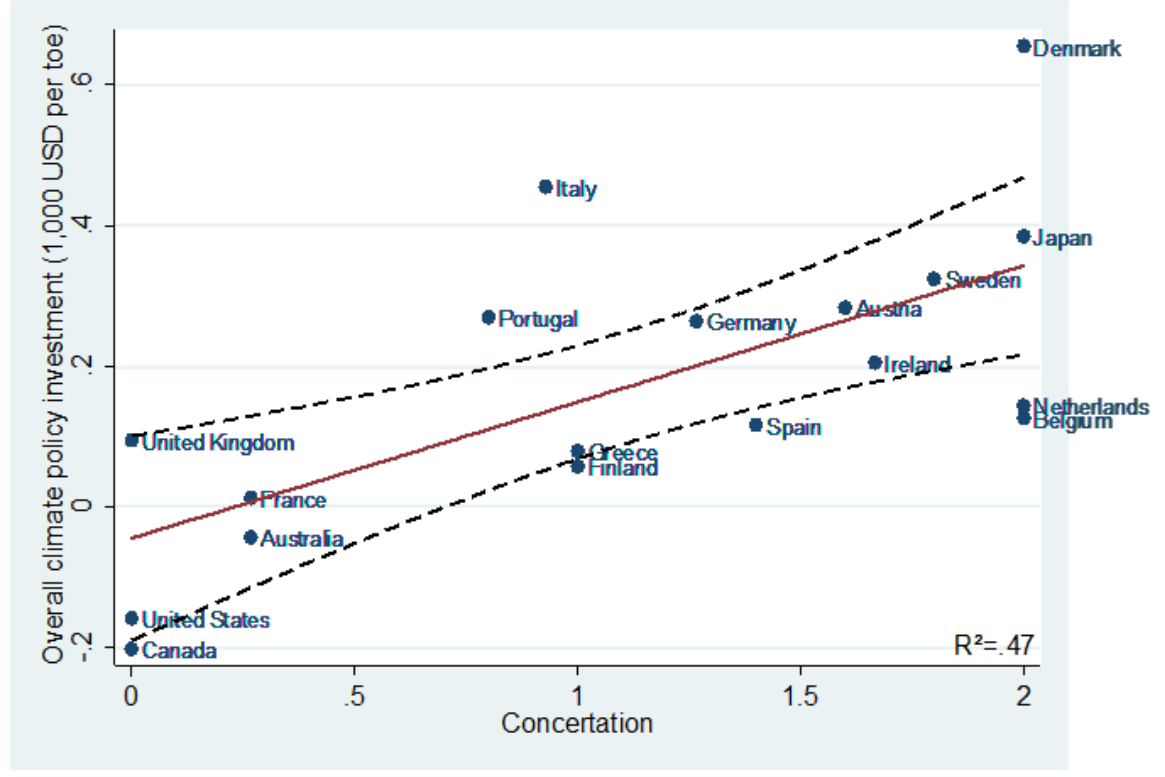

$2000 .{ }^{22}$ A second set of confounders are institutional veto points, especially those that constitute competitive veto points which can enable climate policy opponents to block policy change (Birchfield and Crepaz 1998; Harrison and Sundstrom 2010; Karapin 2016; Madden 2014). These include federalism, strong bicameralism, and presidentialism. To control for these institutional features while maintaining parsimony, I generate an additive index using data from Armingeon et al. (2016). The green policy preferences of governments may also matter. I control for the "greenness" of governments using a new measure from Jahn (2016), who estimates the extent to which governing party(ies) are green- versus growth-oriented based on their manifestos. In addition to capturing green policy preferences, the measure should provide a proxy for underlying voter preferences regarding the environment - if we assume that party preferences track voter preferences. A valid cross-national measure of public opinion for the time period under analysis is not available. ${ }^{23} \mathrm{~A}$ country's production of fossil fuels may influence the government's decision to increase the price of carbon-based energy (Harrison 2015; Hughes and Urpelainen 2015). I therefore control for domestic fossil fuel (coal, oil, and natural gas) production per capita. Lastly, I control for the politics of "economy versus environment", as well as general economic conditions, by including real GDP growth. ${ }^{24}$ While this parsimonious set of controls is my preferred specification, the results are robust to a variety of additional controls and different specifications. ${ }^{25}$

\footnotetext{
${ }^{22}$ Most importantly, the EU has adopted the Renewable Electricity Directive in 2001, ratified the Kyoto Protocol in 2002, and launched the EU Emissions Trading Scheme in 2005.

${ }^{23}$ See Appendix A8 for an analysis of available measures of public opinion.

${ }^{24}$ For descriptions of each variable and summary statistics see Appendix A2.

${ }^{25}$ See Appendix A4.
} 
The advantage of hybrid models is that they simultaneously estimate both between- and within-country effects. Indeed, the estimates of "within" effects are very similar to those obtained by fixed effects models. These estimates control for all time-invariant factors at the country level that may affect climate policy, such as other institutions (e.g., EU membership, institutional veto points, and electoral rules), as well as slow-moving variables like generalized trust and culture. I also include year fixed effects to control for all time-varying factors that affect all countries equally, such as international climate change negotiations, increasing global public awareness regarding climate change, and common energy and economic shocks. Lastly, I use robust standard errors clustered at the country level to correct for serial correlation and heteroscedasticity.

Table 1 presents the results. Both between countries and within them over time, concertation is associated with higher overall policy investment, as expected (Model 1). Furthermore, the institution influences short-term costs for consumers and producers in distinct ways. Again both between and within countries, concertation has a much larger and significant effect on costs for consumers compared to producers (Models 2 and 3). This distributive effect can be seen clearly in Figure 7. At low levels of concertation, there is a smaller difference between costs imposed on consumers relative to producers. However, this difference increases with levels of concertation. This finding is confirmed by Model 4, which shows that concertation is significantly associated with a larger difference between the costs imposed on households versus industry. Put differently, concertation is associated with higher levels of compensation for industry, as predicted.

Surprisingly, I find that concertation has a positive, but not statistically significant, effect on costs for producers. One reason may be the widespread use of negotiated agreements in corporatist countries. Since the early 1990s, governments in countries such as Denmark, the Netherlands, and Germany have relied on voluntary commitments by industry to reduce $\mathrm{CO}_{2}$ emissions instead of implementing energy taxes (Baranzini and Thalmann 2004; Delmas and Terlaak 2002). As mentioned, one drawback of the policy stringency data is that it does not capture these types of government actions. Still, plotting industrial policy stringency against concertation we observe a generally positive relationship, albeit with two outliers: Italy and Netherlands. ${ }^{26}$

${ }^{26}$ See Appendix A5. 
Table 1. Concertation and climate policy investment: Hybrid models

\begin{tabular}{|c|c|c|c|c|}
\hline & $\begin{array}{l}\text { (1) } \\
\text { Overall cli- } \\
\text { mate policy } \\
\text { investment }\end{array}$ & $\begin{array}{c}(2) \\
\text { Costs for } \\
\text { consumers }\end{array}$ & $\begin{array}{l}\text { (3) } \\
\text { Costs for } \\
\text { producers }\end{array}$ & $\begin{array}{c}(4) \\
\text { Difference } \\
\text { in costs }\end{array}$ \\
\hline \multicolumn{5}{|l|}{ Between-country effects } \\
\hline \multirow[t]{2}{*}{ Concertation } & $0.141^{* *}$ & $0.264^{* * *}$ & 0.0254 & $0.238^{* * *}$ \\
\hline & $(0.0565)$ & $(0.0910)$ & $(0.0377)$ & $(0.0792)$ \\
\hline \multirow[t]{2}{*}{ EU Membership } & 0.108 & $0.309^{*}$ & -0.0818 & $0.391^{* * *}$ \\
\hline & $(0.0966)$ & $(0.158)$ & $(0.0542)$ & $(0.132)$ \\
\hline \multirow[t]{2}{*}{ Institutional constraints } & -0.0208 & -0.0203 & $-0.0214^{*}$ & 0.00112 \\
\hline & $(0.0156)$ & $(0.0247)$ & $(0.0114)$ & $(0.0219)$ \\
\hline \multirow[t]{2}{*}{ Green policy preferences } & 0.00808 & $0.0174^{* *}$ & -0.000661 & $0.0180^{* * *}$ \\
\hline & $(0.00492)$ & $(0.00759)$ & $(0.00307)$ & $(0.00586)$ \\
\hline \multirow[t]{2}{*}{ Fossil fuel production } & 0.00363 & 0.0311 & $-0.0222^{* * *}$ & $0.0534^{* *}$ \\
\hline & $(0.0171)$ & $(0.0285)$ & $(0.00857)$ & $(0.0237)$ \\
\hline \multirow[t]{2}{*}{ Real GDP growth } & $-0.0713^{* *}$ & $-0.123^{* * *}$ & -0.0229 & $-0.0996^{* * *}$ \\
\hline & $(0.0361)$ & $(0.0432)$ & $(0.0349)$ & $(0.0302)$ \\
\hline \multicolumn{5}{|l|}{ Within-country effects } \\
\hline \multirow[t]{2}{*}{ Concertation } & $0.0460^{* *}$ & $0.0740^{* * *}$ & 0.0197 & $0.0543^{* * *}$ \\
\hline & $(0.0202)$ & $(0.0283)$ & $(0.0142)$ & $(0.0185)$ \\
\hline \multirow[t]{2}{*}{ Green policy preferences } & 0.00239 & 0.00244 & 0.00235 & 0.000114 \\
\hline & (0.00191) & (0.00238) & (0.00182) & $(0.00178)$ \\
\hline \multirow[t]{2}{*}{ Fossil fuel production } & 0.00480 & 0.0123 & -0.00229 & 0.0145 \\
\hline & $(0.0142)$ & $(0.0191)$ & $(0.0113)$ & $(0.0126)$ \\
\hline \multirow[t]{2}{*}{ Real GDP growth } & -0.00491 & -0.00986 & -0.000242 & -0.00962 \\
\hline & $(0.00463)$ & $(0.00859)$ & $(0.00287)$ & $(0.00862)$ \\
\hline Year FE & Yes & Yes & Yes & Yes \\
\hline $\mathrm{R}^{2}-$ within & 0.368 & 0.384 & 0.277 & 0.273 \\
\hline $\mathrm{R}^{2}$ - between & 0.725 & 0.758 & 0.490 & 0.691 \\
\hline $\mathrm{R}^{2}-$ overall & 0.673 & 0.716 & 0.451 & 0.668 \\
\hline Countries & 18 & 18 & 18 & 18 \\
\hline$N$ & 268 & 268 & 268 & 268 \\
\hline
\end{tabular}


Figure 7. Concertation and distribution of costs between consumers and producers

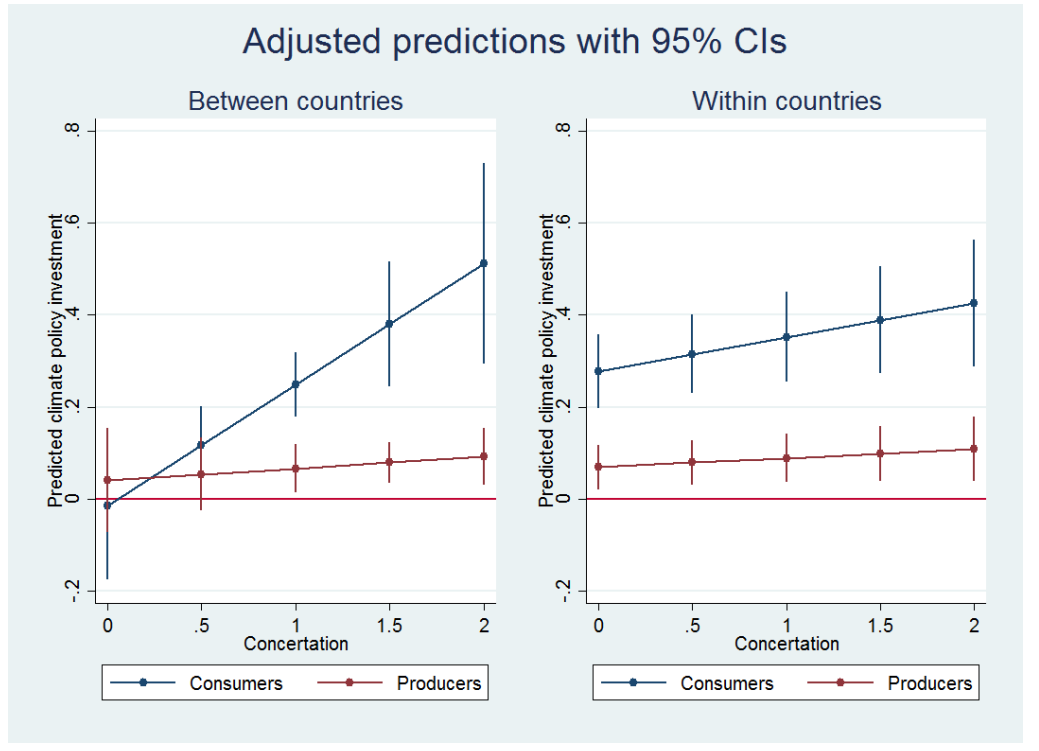

Overall, the results lend support to the argument that institutions for interest group intermediation affect climate policy investment. Concertation increases overall levels of climate policy stringency both between countries and within them over time. Furthermore, a distinct distributive profile underlies these investments. The short-term costs of policy are shifted toward consumers and away from producers. These policy concessions constitute compensation for producers. In return, industry supports the governments' climate policy agenda, leading to higher overall levels of climate policy investment, achieved primarily through increased costs for voters. This can be seen clearly in Figure 8. It is precisely those countries that offer compensation to producers, by distributing higher costs toward voters, which have the highest overall levels of climate policy investment. Denmark is the extreme example. It has the highest average overall stringency in the sample. Consumers there paid on average 1,000 USD more per unit of carbon-based energy than producers over the sample period. We see then that close and institutionalized relationships between industry and government facilitate climate policy. This finding runs counter to conventional thinking that polluters always oppose climate policy (e.g., Hughes and Urpelainen 2015); highlighting instead the crucial role that institutions play in structuring the incentives of these actors to cooperate with the government.

\subsection{Institutional complementarities}

Lastly, I test how the joint presence of electoral rules and interest group intermediation affect climate policy investments. As a first step, I extract the first principal component of electoral 
Figure 8. Distribution of costs and overall policy investment (with 95\% CIs) (avg 1995-2009)

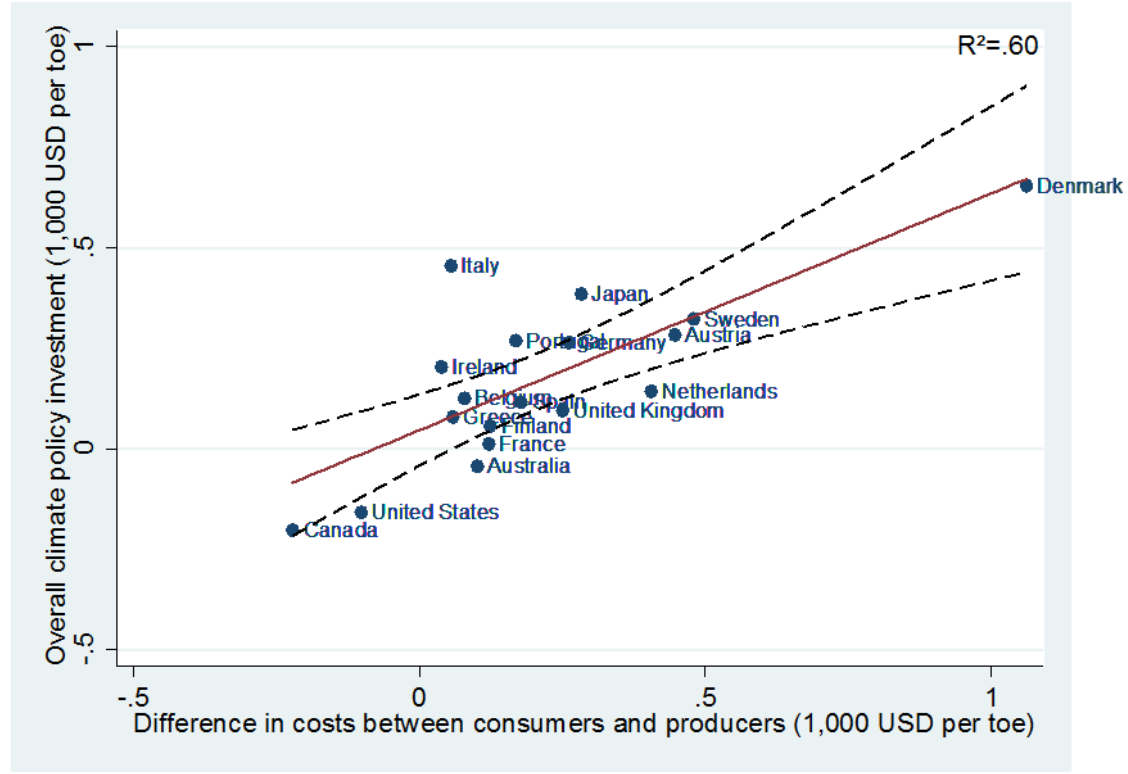

disproportionality and concertation. The resulting variable measures countries along a spectrum ranging from the joint presence of PR rules and concertation to the joint presence of plurality rules and interest group pluralism. The measure is highly correlated with Lijphart's measure of consensus democracy (0.85), which is unsurprising since electoral rules and interest group intermediation constitute the institutional basis of his conceptualization. Plotting the new variable against overall climate policy investment reveals a positive relationship (Figure 9). Consensus democracies with both PR rules and concertation have higher levels of investment compared to majoritarian ones with first-past-the-post rules and interest group pluralism. Cross-sectional OLS models with controls confirm the robustness of this result. ${ }^{27}$

To investigate the relationship further, I again exploit within-country variation in concertation to estimate its effect at different levels of electoral disproportionality using fixed effects models. My arguments predict that the positive effect of concertation is strongest under PR rules. Table 2 presents the results and Figure 10 presents the marginal effects of four models. As expected, concertation has the largest and most significant positive effect on climate policy investment when electoral rules are more proportional, all else equal (Figure 10 - top left). The result is similar when predicting costs for consumers and producers (Figure 10 - top right and bottom left). In the case of the difference in costs, the coefficient has a negative sign, but doesn't reach conventional levels of significance (Figure 10 - bottom right). This may be because the estimates rely on within-country variation in concertation in 9 of the 18 countries in the sample, reducing

${ }^{27}$ See Appendix A6. 
Figure 9. Institutional complementarities and overall policy investment (with 95\% CIs) (avg 19952009)

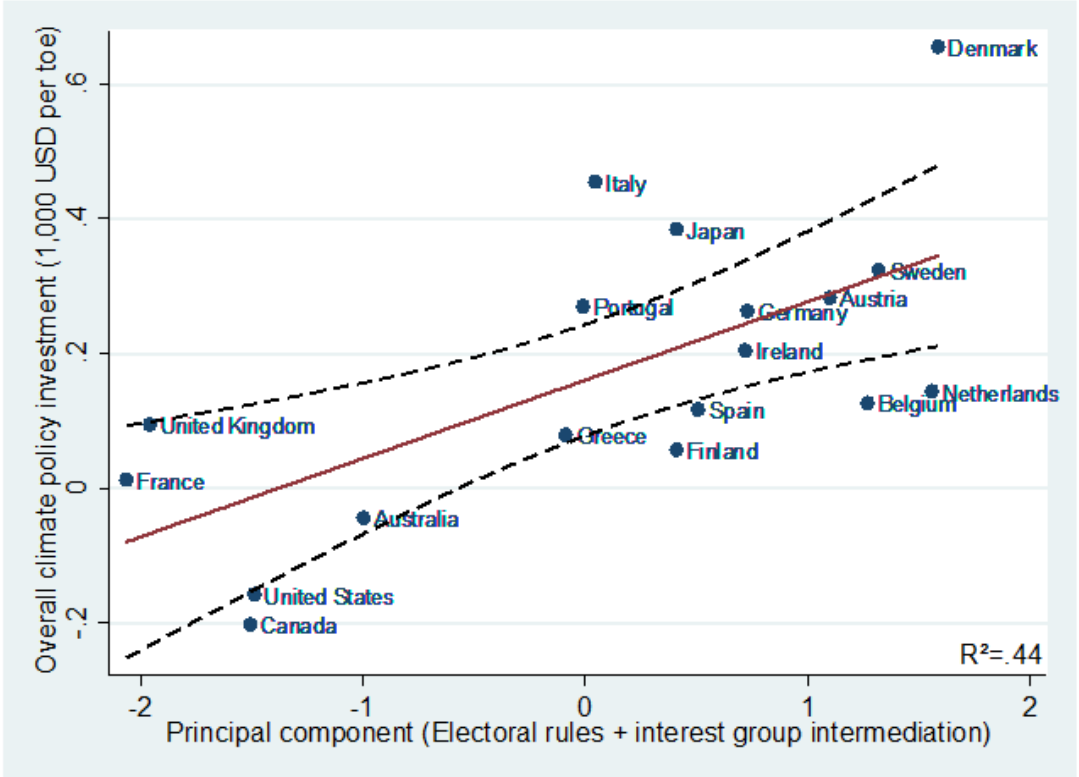

Table 2. Institutional complementarity and climate policy investment: Fixed effects models

\begin{tabular}{|c|c|c|c|c|}
\hline & $\begin{array}{l}\quad(1) \\
\text { Overall cli- } \\
\text { mate policy } \\
\text { investment }\end{array}$ & $\begin{array}{c}\text { (2) } \\
\text { Costs for } \\
\text { consumers }\end{array}$ & $\begin{array}{l}\text { (3) } \\
\text { Costs for } \\
\text { producers }\end{array}$ & $\begin{array}{c}(4) \\
\text { Difference } \\
\text { in costs }\end{array}$ \\
\hline Concertation $(\mathrm{t}-1)$ & $\begin{array}{l}0.0847^{* *} \\
(0.0318)\end{array}$ & $\begin{array}{c}0.117^{* *} \\
(0.0429)\end{array}$ & $\begin{array}{l}0.0606^{* *} \\
(0.0282)\end{array}$ & $\begin{array}{l}0.0563^{*} \\
(0.0311)\end{array}$ \\
\hline Electoral disproportionality $(\mathrm{t}-1)$ & $\begin{array}{c}0.00338 \\
(0.00200)\end{array}$ & $\begin{array}{c}0.00539 \\
(0.00332)\end{array}$ & $\begin{array}{c}0.00108 \\
(0.00190)\end{array}$ & $\begin{array}{c}0.00431 \\
(0.00358)\end{array}$ \\
\hline Concertation $*$ Electoral dis. $(\mathrm{t}-1)$ & $\begin{array}{c}-0.00766^{*} \\
(0.00398)\end{array}$ & $\begin{array}{c}-0.00908^{*} \\
(0.00444)\end{array}$ & $\begin{array}{l}-0.00633 \\
(0.00369)\end{array}$ & $\begin{array}{l}-0.00275 \\
(0.00218)\end{array}$ \\
\hline Green policy preferences $(\mathrm{t}-1)$ & $\begin{array}{c}0.00180 \\
(0.00145)\end{array}$ & $\begin{array}{c}0.00171 \\
(0.00167)\end{array}$ & $\begin{array}{c}0.00186 \\
(0.00159)\end{array}$ & $\begin{array}{c}-0.000151 \\
(0.00155)\end{array}$ \\
\hline Fossil fuel production $(\mathrm{t}-1)$ & $\begin{array}{l}0.00417 \\
(0.0135)\end{array}$ & $\begin{array}{c}0.0104 \\
(0.0175)\end{array}$ & $\begin{array}{c}-0.00204 \\
(0.0116)\end{array}$ & $\begin{array}{c}0.0125 \\
(0.0121)\end{array}$ \\
\hline Real GDP growth (t-1) & $\begin{array}{l}-0.00452 \\
(0.00575)\end{array}$ & $\begin{array}{c}-0.0113 \\
(0.00863)\end{array}$ & $\begin{array}{c}0.00168 \\
(0.00458)\end{array}$ & $\begin{array}{c}-0.0130 \\
(0.00755)\end{array}$ \\
\hline Country FE & Yes & Yes & Yes & Yes \\
\hline Year FE & Yes & Yes & Yes & Yes \\
\hline $\mathrm{R}^{2}-$ within & 0.395 & 0.402 & 0.316 & 0.282 \\
\hline $\mathrm{R}^{2}-$ between & 0.212 & 0.270 & 0.041 & 0.074 \\
\hline $\mathrm{R}^{2}-$ overall & 0.204 & 0.216 & 0.101 & 0.081 \\
\hline Countries & 18 & 18 & 18 & 18 \\
\hline$N$ & 268 & 269 & 269 & 269 \\
\hline
\end{tabular}

Robust standard errors in parentheses clustered at the country level. ${ }^{*} p<0.10,{ }^{* *} p<0.05,{ }^{* * *} p<0.01$ 
Figure 10. Institutional complementarities and policy investment: Marginal effects
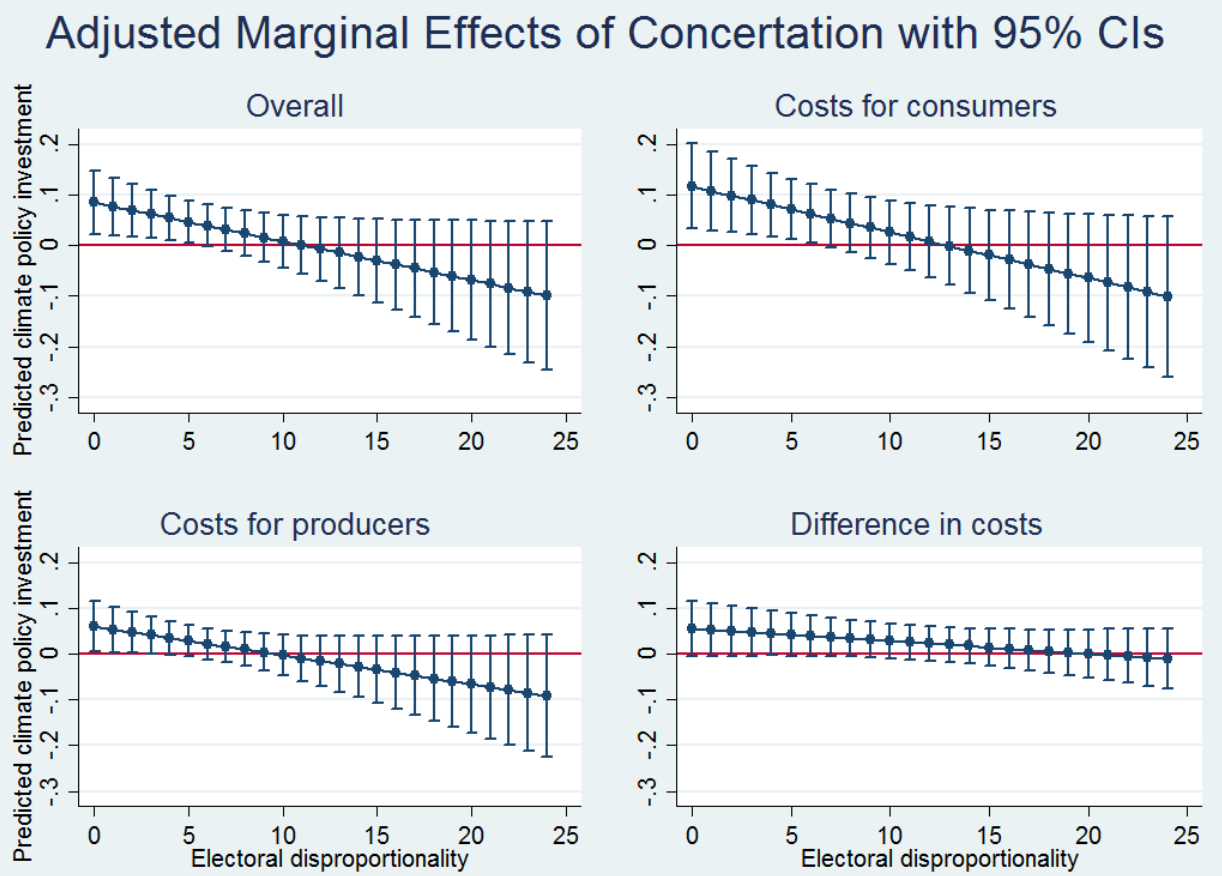

statistical power. Overall, however, the evidence supports my arguments. Electoral rules and interest group intermediation complement one another. Governments are able to achieve higher levels of climate policy investment when both institutions are jointly present. For this reason, we also observe a positive and significant relationship between consensus democracy more generally and climate change policy. ${ }^{28}$

\section{Varieties of decarbonization}

I have theorized how institutions drive cross-national variation in long-term climate policy investment and provided evidence to support of my arguments. I show that countries with PR rules and corporatism have the highest levels of climate policy investment. Here I build on my findings to offer broader theorizing about how institutional diversity generates two ideal-type political-economic models - negotiated and competitive, which in turn produce distinct varieties of decarbonization. ${ }^{29}$ Comparing climate policy investments over time across these two types of countries we see a clear pattern (Figure 11). Policy investments are much higher in negotiated political economies, as are costs for consumers and producers. In addition, stringency for both groups began increasing

28 See Appendix A7.

${ }^{29}$ Thank you to David Soskice for suggesting this vocabulary. 
Figure 11. Varieties of decarbonisation and climate change policy investment over time ${ }^{30}$

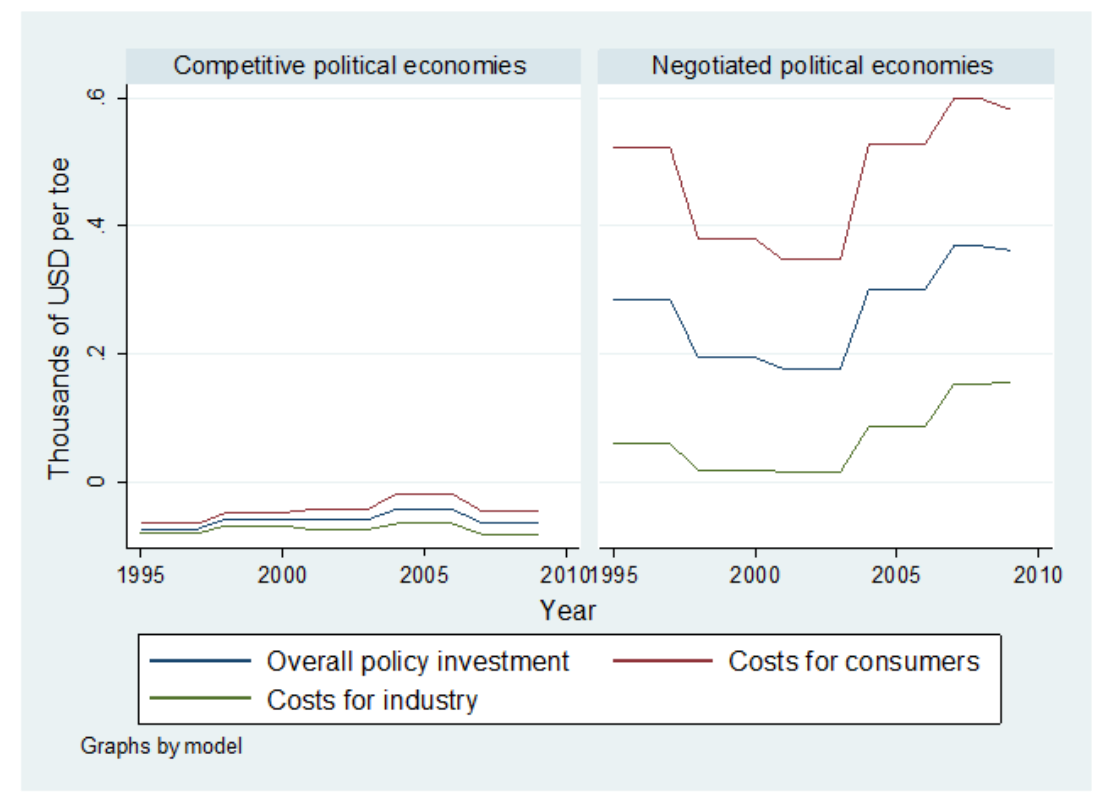

around 2003. Below I offer an account of a broader set of mechanisms that should drive this variation, which future research can expand and test.

\subsection{The negotiated model}

The negotiated model is characterized by inclusiveness, representation, bargaining, and compromise (Huber and Powell 1994, 298; Lijphart 2012, 2). Institutions aim to broaden participation in government and incentivize actors to achieve agreement on the policies that the government should pursue (Lijphart 2012, 2). In "inclusive negotiations" social actors "act toward collective instead of individualistic interests, think about long-term impacts on future generations, and focus on substantive rather than political goals" (Martin 2015, 23). It is important to note that consensus does not mean the absence of disagreement between powerful actors. Rather, it refers to generalized political exchange at an institutional level (Crouch 1993, 53). Consensus democracies accept and take for granted "a mass of conflicts, but [process] them in such a way that, unless something goes drastically wrong with the balance, the likelihood of recourse to open conflict is reduced, and actors [are] enabled to trade gains in one arena for losses in another" (Crouch 1993, 53-54). Archetypal negotiated political economies include the consensus-based coordinated market economies of Austria, Belgium, Germany, the Netherlands, Scandinavia, and Switzerland.

\footnotetext{
${ }^{30}$ Included archetypal competitive political economies are: Australia, Canada, France, the UK, and the US. Included archetypal negotiated political economies are: Austria, Belgium, Denmark, Finland, Germany, Netherlands, and Sweden.
} 
Given the centripetal political incentives generated by the need for coalition bargaining and inclusive legislative institutions, we should expect early cross-party party consensus on the problem of climate change and the need for action. Furthermore, these political economies should tend to rely on nonpartisan, expert legislative commissions to gather information and propose policies (Martin 2015). For example, it was within the framework of the landmark "Inquiry Commission on Preventive Measures to Protect the Atmosphere" ${ }^{31}$, that beginning in 1987 the first policy responses to climate change were formulated in Germany (Hatch 1995, 426; Michaelowa 2003, 32; Weidner and Mez 2008, 362). The commission brought together scientific experts, industry associations, and prominent politicians (representative of the parties in parliament and chosen for their ties to important social groups and policy expertise) to deliberate and bargain - and "out of this process emerged a broad consensus for political action" (Hatch 1995, 426).

As detailed in this paper, we should expect a distinct distributive bargain to underpin climate policy investments, facilitated by the complementary between PR and corporatism. The costs of policy change are initially pushed toward consumers and away from producers. For this reason, governments will tend to rely on policy instruments that directly affect consumer prices, such as taxes and fees, rather than those that target industry, such as efficiency standards. Indeed, this is precisely the way that Scandinavian countries have become forerunners in climate policy (Daugbjerg and Pedersen 2004; Kasa 2000; Midttun and Hagen 1997; Mildenberger 2018). Through negotiation and bargaining, politicians and cost-bearing organized groups reached agreement in the early 1990s on carbon taxation that entailed significant exemptions for energy-intensive industries and shifted costs onto consumers. In return, producers supported government efforts to address climate change and little public conflict ensued. Crucially, the complementarity between $\mathrm{PR}$ and corporatism changes the payoffs to industry of pursuing different strategies in response to government action. It makes it less costly for industry to directly negotiate an agreement with the government than to launch a public campaign attempting to block policy change. In this way, privileged access should reduce "climate scepticism". In Austria, for example, obstruction and public climate change denial by industry is not necessary because peak associations for employers and labour can pre-screen and filter policy change through their privileged access to policymaking (Brand and Pawloff 2014, 791).

The adoption of early, moderate policy should enable governments to incrementally ratchet up policy stringency for producers over time. There is evidence that this is already underway. For example, after years of industry enjoying a much lower carbon tax rate than households, the Swedish government equalized tax rates across both groups in 2018 (Government of Sweden,

\footnotetext{
${ }^{31}$ Enquete-Kommission des Bundestags "Vorsorge zum Schutz der Erdatmosphäre"
} 
2019). Moreover, we see that after a period of low, stable costs for producers, costs begin to increase for industry around 2003 (Figure 11). These arguments stand in contrast to those made by a number of scholars who propose that close links between powerful economic actors and government enable industry to "capture" the climate policymaking process and prevent significant action. ${ }^{32}$ I find little evidence of this. Comparatively, these types of political economies have the highest overall levels of policy stringency, as well as the highest costs for industry.

Climate policy should also be more credible in these countries, which should increase certainty among social actors that its associated long-term benefits will actually accrue - further providing the necessary conditions for long-term policy investment (Jacobs 2011). Inclusive legislative committee rules decentralize the policymaking process, ensuring that governing and opposition parties are represented (Fortunato et al., 2017; Martin and Vanberg 2011; Powell 2000; Mattson and Strøm 1995, 277-278). This increases the number of cooperative veto points, making it less likely that a new government is able to deviate from a previous agreement without securing the buy-in of opposition parties and their allied interest groups. ${ }^{33}$ At the same time, because individual firms are organized into peak associations that have the authority to commit to policy on behalf of their members and sanction non-compliance, it is difficult and costly for rogue firms to upend the collective agreement by either free-riding on the efforts of other firms or publicly challenging the agreement. Furthermore, repeated interactions through established corporatist channels fosters trust on both sides, which serves to further attenuate perceptions of risk about unexpected policy reversal or non-compliance. The result should be interlocking credibility. All groups can enter into long-term agreements with the confidence that the bargain will be upheld. Policy variance and regulatory uncertainty should be reduced, which incentivizes firms to undertake risky and expensive long-term investments in less carbon-intensive production processes. What is more, the process may be self-reinforcing. Interested actors make decisions based on the credibility and stability of policy, which generates incentives to preserve those policy commitments, so as to reap the long-term benefits. As a result, climate policy reversals should be rare as positive feedback effects and path dependency take over.

Lastly, we should expect climate policy investment to stall in times of heightened electoral competitiveness, since these conditions will reduce electoral safety and make it more risky for politicians to impose additional costs on loss-averse voters. Policy investment should also stall if cross-party consensus breaks down, which may occur if populist or extreme parties that openly

\footnotetext{
32 For example in Austria (Brand and Pawloff 2014; Tobin 2017), Germany (Meckling and Nahm 2018), and Norway (Mildenberger 2018).

${ }^{33}$ For a description of the Danish case see Toke and Nielsen (2015).
} 
question climate change win substantial legislative seats. Lastly, policy should he hindered if large and unanticipated losses emerge for industry, as they should be expected to use their privileged access to bargain for reduced policy stringency (Jacobs and Weaver 2015, 445). Conversely, if policy stringency can be incrementally increased, we should expect these political economies to lead on innovation in clean technologies, since policy stringency is a major driver of such innovation (Aghion et al. 2016; Calel and Dechezleprêtre 2016).

\subsection{The competitive model}

The competitive model is exclusive and adversarial (Lijphart 2012, 1). Elections are designed to produce "strong, single-party governments that are essentially unconstrained by other parties in the policy-making process" (Huber and Powell 1994, 291). Here "distributive bargaining" entails "zero-sum exchanges and particularistic pay-offs, exclude[s] the interests of those not represented at the table, and neglect[s] long-term consequences" (Martin 2015, 23). Archetypal competitive political economies include the majoritarian liberal market economies of Australia, Canada, the UK, and the US.

Majoritarian electoral rules mean that two, typically patronage rather than programmatic, political parties are locked in fierce electoral competition over marginal votes, while exclusive legislative committees enable the governing party to dominate policymaking (Powell 2000). To influence policy, the only hope for the opposition party is to win the next election. In an effort to do so, it will face strong incentives to turn climate into a partisan issue and compete with the governing party on it. Under such conditions, the two main parties will have few incentives to cultivate and sustain cross-party consensus on long-term climate policy, leading to conflict and gridlock. For this reason, we should not expect these countries to be early policy adopters.

Given the power of the governing party, partisanship should be the key driver of climate policy investment. Investment should wax and wane dramatically depending on which of the two parties is in power. However, if and when cross-party consensus on climate materializes, it should drive policy investment. For example, it was during an "extraordinary moment" of cross-party consensus from 2006 to 2008 that climate change became a valence issue in the UK, enabling the Labour government to adopt the country's flagship Climate Change Act (Carter 2014, 425; Carter and Clements 2015, 210; Lockwood 2013, 1344). ${ }^{34}$ Because it increases electoral safety, reduced

\footnotetext{
${ }^{34}$ Some suggest that this consensus quickly broke down after the 2010 election as the right wing of the Conservative Party became hostile toward climate policy, especially "green taxes", returning climate to its previous status as a partisan issue (Carter 2014, 429; Carter and Clements 2015, 215-217; Gillard 2016).
} 
electoral competitiveness should also increase the likelihood of policy investment, as would enabling politicians to push the short-term costs of investment into the future, beyond the next election. For example, under the UK's Climate Change Act parliamentarians set policy targets twelve years in advance. Such an approach helps to relieve the short-term pressures of electoral accountability.

When climate policy investments do occur, they will tend to be underpinned by a distributive profile that directs short-term costs toward producers and away from consumers, as detailed in this paper. The result is that politicians will tend to utilize policy instruments that hide the costs of policy change from voters, such as subsidies, tax credits, research and development spending, and other public investments financed through general revenues rather than through directly increasing consumer prices. They should also rely on supply-side policies aimed at changing the production processes of carbon-intensive firms, such as efficiency standards (e.g., for automobiles and power plants) and renewable energy quotas for utilities, for example. Indeed, in Australia, Canada, the UK and the US, scholars have noted a considerable aversion amongst politicians to imposing short-term costs on voters, as well as the high political saliency of climate policy costs (Lockwood 2016; MacNeil 2015; Rabe 2010). Furthermore, major climate policy investments in these countries have tended to push significant costs toward industry, including: the Climate Change Levy in the UK, the Carbon Pricing Mechanism in Australia, and the Clean Power Plan in the US (Jotzo 2012; Pearce 2006).

However, the problem is that, due to interest group pluralism, politicians lack the capacity to negotiate credible compensation for organized cost-bearing groups. Rather than encompassing organizations, industry is loosely organized into associations of interests that compete for political influence and policy concessions. Under these conditions, the government and cost-bearing groups will find negotiation and bargaining difficult to sustain. For example, the US Environmental Protection Agency received 1,762 public comments from companies and organizations on proposed rules for emissions standards under the Clean Power Plan (EPA 2018). Strikingly, there was no common position among individual utilities or industry associations on how the rules should look (Downie 2017). Similarly, in 1993 in the US, President Clinton's plans to implement a broadbased energy tax in an effort to combat climate change fell apart as a multitude of companies and interest groups competed to secure particularistic advantages rather than negotiate a broad-based agreement (Erlandson 1994, 183; Wines 1993).

Ignoring cost-bearing organized groups should enable governments in these countries to adopt more radical policy change. However, the strategy will also antagonize industry, who, by being shut out of private negotiations, will tend to respond by expanding the scope of distributive 
conflict to the public square. Indeed, this mechanism helps to explain the particularly Anglo-Saxon flavor of climate scepticism (Tranter and Booth 2015). Industry should also be likely to resort to the courts to block policy change. In the US for example, firms are accustomed to highly adversarial relations with government institutions and expect to engage in extensive lobbying and frequent litigation, rather than deliberation, to influence climate policy in their preferred direction (Brewer 2014, 61). That said, we should expect industry buy-in when governments and industry are able to re-create corporatist style bargaining and negotiation over compensation for short-term costs. For example, in the UK, bargaining between the Labour government and industry associations secured industry buy-in for the Climate Change Agreements (Bailey and Rupp 2006). ${ }^{35}$

Long-term climate policy investments should also enjoy less credibility. Single-party governments and government-dominated legislative committees reduce the number of veto points in the policymaking process, as does the lack of corporatist linkages between peak associations and the policymaking process. New governments are empowered to change policy quickly and dramatically after an election. From the perspective of firms, these conditions create regulatory uncertainty, reducing incentives to make expensive long-term investments in less carbon-intensive production processes. For example, since its creation in 1992, consecutive US governments have allowed the Production Tax Credit (PTC) (a tax exemption for renewable electricity generation) to expire and be extended six times, creating a boom-and-bust cycle in renewable energy investment and development, especially wind power (Barradale 2010; UCS 2017). In the UK, constant changes to renewable energy and carbon pricing policy, caused by party disagreements, are blamed for generating policy uncertainty amongst investors (Ares and Delebarre 2016, 18; Lockwood 2013, 1346; Wood and Dow 2011, 2239).

Rather than engage in deliberative bargaining, having few veto points incentivizes an anticlimate opposition party and its allied interest groups to oppose, delay, and block climate policy investment until their side comes to power, at which point they can reverse course. For this reason, competitive political economies are likely to be characterized by frequent policy reversals and a general lack of self-reinforcing policies. In Australia, for example, the centre-left Labor government implemented a carbon price in 2011 only to have it repealed once the new centre-right Liberal/National government came to power three years later (MacNeil 2015, 29-31; Rootes 2014). In 2015, the Democratic US President Barack Obama signed the Paris Climate Agreement and adopted the Clean Power Plan (the country's only major climate policy investment). Two years

\footnotetext{
${ }^{35}$ In exchange for entering into these legally binding emission reductions agreements, firms in energyintensive sectors can receive reduction in their liabilities under the Climate Change Levy (a flat tax in carbon-intensive energy use).
} 
later however, the new Republican President Donald Trump announced the country's withdrawal from the Paris Climate Agreement and his intention to eliminate the Clean Power Plan. Precisely because credible commitment will be particularly difficult, politicians wanting to address climate change should be more likely to create institutions that bind the hands of future governments, such as long-term statutory reduction targets and delegation to independent advisory and/or regulatory bodies - two strategies used in the UK.

\section{Conclusion}

This paper offers a theoretical framework rooted in domestic institutions that explains the wide variation in climate policy investment across the advanced capitalist democracies. Institutions matter because they influence the necessary conditions for policy investment to occur. Most importantly, they shape electoral safety and structure the ability of governments to overcome opposition from organized cost-bearing groups. PR rules increase electoral safety by decreasing clarity of responsibility and electoral competitiveness, which in turn enables governments to impose short-term costs on their constituents. Concertation facilitates bargaining between the government and powerful economic actors over compensation for the losers of policy change, which helps governments overcome industry opposition. What is more, the joint presence of both institutions generates powerful complementarities that reinforce their independent effects. PR rules decrease risks associated with shifting costs toward voters, which opens up critical room to maneuver when negotiating compensation with cost-bearing groups.

By structuring the distributive politics of climate change, institutional complementarities generate distinct varieties of decarbonization that should drive differences in climate policy investments across these countries. On the one hand are negotiated political economies with consensus-based democratic institutions and coordinated market economies. Here climate policy should tend to enjoy relative cross-party consensus, support from cost-bearing industry, and low public conflict. Moreover, policy change is likely to be incremental rather than radical and offer compensation to losers. On the other hand are competitive political economies with majoritarian democracies and liberal market economies. Here climate policy investments are likely to enjoy little cross-party support or support from cost-bearing producers. Policy change is more likely to be radical and ignore losers. As a result, public conflict will tend to be high and policy reversals more frequent.

These arguments bring together two important streams in the literature on the comparative political economy of climate policy. Lipscy (2018) demonstrates the effect of electoral rules on 
climate-related policy adoption, while Mildenberger (2018) and others show the effect of corporatism. My arguments seek to elucidate the complementarity between the two and shed light on how packages of institutions work together to affect climate policy investment. By doing so, the paper contributes to filling large theoretical gaps in the climate change politics literature. It also highlights a number of areas for future research. First, the arguments require additional tests. For example, future work could examine the hypotheses outlined here regarding the link between electoral rules and climate policy credibility, electoral rules and party positions on climate change, and corporatism and climate change scepticism. Second, research is needed that examines the effect of other complementarity institutions, especially legislative committees, corporate governance structures, and welfare states, as well as possible international complementarities between different varieties of decarbonization. Lastly, additional measures of climate policy investment, especially time series data that reach back into the 1980s, are needed to analyze the effect of institutions over longer time horizons.

The results are also broadly consistent with Jacobs' (2011) theoretical arguments. Countries are able to achieve higher levels of climate policy investment when politicians have a low risk of losing office and can reach credible and stable distributive bargains with cost-bearing organized groups. However, the paper also extends the long-term politics literature to climate change - a long-term problem whose future costs and benefits cannot be redistributed. Under these conditions, I find that the opportunities for and constraints on short-term cross-sectional distribution are crucial. Those countries that distribute short-term policy costs toward voters and away from industry (i.e., simultaneous cross-sectional and intertemporal redistribution) are also those that have higher overall levels of climate policy investment. In contrast, those that impose similar shortterm costs on both groups (i.e., pursue vertical investment) have lower levels of overall investment. This suggests a relationship between types of policy investment and overall levels of investment.

Lastly, the analysis illuminates causal mechanisms that should enable consensus democracies to better address a wide range of long-term policy challenges apart from climate change. Previous scholars have suggested this hypothesis (Birchfield and Crepaz 1998; Crepaz 1996; Lindvall 2017, Ch 5). This paper links institutions present in these political economies to one type of longterm policy. Additional research is needed to further test the relationship across a variety of policy areas. 


\section{References}

Aghion, Philippe, Antoine Dechezleprêtre, David Hémous, Ralf Martin, and John Van Reenen. 2016. "Carbon Taxes, Path Dependency, and Directed Technical Change: Evidence from the Auto Industry.” Journal of Political Economy 124 (1): 1-51. https://doi.org/10.1086/684581.

Aklin, Michaël, and Johannes Urpelainen. 2013. "Political Competition, Path Dependence, and the Strategy of Sustainable Energy Transitions." American Journal of Political Science 57 (3): 643-58. https://doi.org/10.1111/ajps.12002.

Althammer, Wilhelm, and Erik Hille. 2016. "Measuring Climate Policy Stringency: A Shadow Price Approach." International Tax and Public Finance 23 (4): 607-39. https://doi.org/10.1007/s10797-0169405-4.

Ares, Elena and Jeanne Delebarre. 2016. “The Carbon Price Floor”. House of Commons Library. Briefing Paper Number CBP05927.

Armingeon, Klaus, Christian Isler, Laura Knopfel, David Weisstanner and Sarah Engler. 2016. Comparative Political Data Set 1960-2013. Bern: Institute of Political Science, University of Berne.

Arrow, Kenneth. 2007. 'Global climate change: A challenge to policy.' The Economists' Voice 4, 3.

Bailey, Ian, and Susanne Rupp. 2006. "The Evolving Role of Trade Associations in Negotiated Environmental Agreements: The Case of United Kingdom Climate Change Agreements." Business Strategy and the Environment 15 (1): 40-54. https://doi.org/10.1002/bse.465.

Baranzini, Andrea, and Philippe Thalmann. 2004. Voluntary Approaches in Climate Policy. E. Elgar Pub.

Barradale, Merrill Jones. 2010. "Impact of Public Policy Uncertainty on Renewable Energy Investment: Wind Power and the Production Tax Credit." Energy Policy, Special Section: Carbon Reduction at Community Scale, 38 (12): 7698-7709. https://doi.org/10.1016/j.enpol.2010.08.021.

Bell, Andrew, and Kelvyn Jones. 2015. "Explaining Fixed Effects: Random Effects Modeling of TimeSeries Cross-Sectional and Panel Data." Political Science Research and Methods 3 (01): 133-153. https://doi.org/10.1017/psrm.2014.7.

Bernauer, Thomas. 2013. "Climate Change Politics.” Annual Review of Political Science 16 (1): 421-48. https://doi.org/10.1146/annurev-polisci-062011-154926.

Bernauer, Thomas, and Tobias Böhmelt. 2013. “Are Economically 'Kinder, Gentler Societies’ Also Greener?” Environmental Science \& Technology 47 (21): 11993-1. https://doi.org/10.1021/es403362m.

Birchfield, Vicki, and Markus M.L. Crepaz. 1998. "The Impact of Constitutional Structures and Collective and Competitive Veto Points on Income Inequality in Industrialized Democracies." European Journal of Political Research 34 (2): 175-200. https:// doi.org/10.1111/1475-6765.00404.

Brand, Ulrich, and Adam Pawloff. 2014. "Selectivities at Work: Climate Concerns in the Midst of Corporatist Interests. The Case of Austria." Journal of Environmental Protection 05 (09): 780-95. https://doi.org/10.4236/jep.2014.59080.

Brewer, Thomas L. 2014. The United States in a Warming World: The Political Economy of Government, Business, and Public Responses to Climate Change. Cambridge: Cambridge University Press. http://ebooks.cambridge.org/ref/id/CBO9781107706569.

Calel, Raphael, and Antoine Dechezleprêtre. 2016. "Environmental Policy and Directed Technological Change: Evidence from the European Carbon Market." The Review of Economics and Statistics 98 (1): 173-91. https://doi.org/10.1162/REST_a_00470. 
Cao, Xun, Helen V. Milner, Aseem Prakash, and Hugh Ward. 2014. "Research Frontiers in Comparative and International Environmental Politics An Introduction." Comparative Political Studies 47 (3): 291308. https://doi.org/10.1177/0010414013509567.

Carter, Neil. 2014. "The Politics of Climate Change in the UK." Wiley Interdisciplinary Reviews: Climate Change 5 (3): 423-33. https://doi.org/10.1002/wcc.274.

Carter, Neil, and Ben Clements. 2015. "From 'Greenest Government Ever' to 'Get Rid of All the Green Crap': David Cameron, the Conservatives and the Environment.” British Politics 10 (2): 204-25. https://doi.org/10.1057/bp.2015.16.

Chang, Eric C. C., Mark Andreas Kayser, Drew A. Linzer, and Ronald Rogowski. 2010. Electoral Systems and the Balance of Consumer-Producer Power. Cambridge: Cambridge University Press. http://ebooks.cambridge.org/ref/id/CBO9780511761423.

Crepaz, Markus M. L. 1995. "Explaining National Variations of Air Pollution Levels: Political Institutions and Their Impact on Environmental Policy-making." Environmental Politics 4 (3): 391-414. https://doi.org/10.1080/09644019508414213.

. 1996. "Consensus Versus Majoritarian Democracy Political Institutions and Their Impact on Macroeconomic Performance and Industrial Disputes." Comparative Political Studies 29 (1): 4-26. https://doi.org/10.1177/0010414096029001001.

Crouch, Colin. 1993. Industrial Relations and European State Traditions. Oxford University Press. http://www.oxfordscholarship.com/view/10.1093/0198279744.001.0001/acprof-9780198279747.

Culpepper, Pepper D. 2010. Quiet Politics and Business Power. Cambridge University Press - M.U.A. https://www-cambridge-org.gate3.library.lse.ac.uk/core/books/quiet-politics-and-businesspower/56127E2EE022EBA207A337E49BFD16B5\#.

Cusack, Thomas R., Torben Iversen, and David Soskice. 2007. "Economic Interests and the Origins of Electoral Systems." American Political Science Review, no. 03 (August): 373-391. https://doi.org/10.1017/S0003055407070384.

Daugbjerg, Carsten, and Anders Branth Pedersen. 2004. "New Policy Ideas and Old Policy Networks: Implementing Green Taxation in Scandinavia.” Journal of Public Policy 24 (02): 219-249. https://doi.org/DOI:10.1017/S0143814X0400011X.

Delmas, Magali, and Ann Terlaak. 2002. "Regulatory Commitment to Negotiated Agreements: Evidence from the United States, Germany, the Netherlands, and France." Journal of Comparative Policy Analysis: Research and Practice 4 (1): 5-29. https:/ /doi.org/10.1080/13876980208412668.

Downie, Christian. 2017. "Fighting for King Coal's Crown: Business Actors in the US Coal and Utility Industries." Global Environmental Politics 17 (1): 21-39. https://doi.org/10.1162/GLEP_a_00388.

Drews, Stefan, and Jeroen C. J. M. van den Bergh. 2015. "What Explains Public Support for Climate Policies? A Review of Empirical and Experimental Studies." Climate Policy 0 (0): 1-22. https://doi.org/10.1080/14693062.2015.1058240.

Environmental Protection Agency (EPA). 2018. "Carbon Pollution Emission Guidelines for Ex-isting Stationary Sources: Electric Utility Generating Units.” Regulations.gov. https://www.regulations.gov/document?D=EPA-HQ-OAR-2013-0602-0001 (accessed March 6, 2018).

Erlandson, D. 1994. “The BTU Tax Experience: What Happened and Why It Happened”,(1994) 12.” Pace Environmental Law Review 1: 173-184.

Fankhauser, Samuel, Caterina Gennaioli, and Murray Collins. 2015a. "Do International Factors Influence the Passage of Climate Change Legislation?" Climate Policy 0 (0): 1-14. https://doi.org/10.1080/14693062.2014.1000814. 
. 2015b. "The Political Economy of Passing Climate Change Legislation: Evidence from a Survey." Global Environmental Change 35 (November): 52-61. https://doi.org/10.1016/j.gloenvcha.2015.08.008.

Finnegan, Jared J. 2018. "Changing Prices in a Changing Climate: Electoral Competitiveness and Fossil Fuel Taxation." Centre for Climate Change Economics and Policy Working Paper 341/ Grantham Research Institute on Climate Change and the Environment Working Paper 307, 54. http://www.lse.ac.uk/GranthamInstitute/wp-content/uploads/2018/10/working-paper-307-Finnegan.pdf.

Fortunato, David, Lanny W. Martin, and Georg Vanberg. 2017. "Committee Chairs and Legislative Review in Parliamentary Democracies." British Journal of Political Science, March, 1-13. https://doi.org/10.1017/S0007123416000673.

Franzen, Axel, and Dominikus Vogl. 2013. "Two Decades of Measuring Environmental Attitudes: A Comparative Analysis of 33 Countries." Global Environmental Change 23 (5): 1001-8. https://doi.org/10.1016/j.gloenvcha.2013.03.009.

Frederick, Shane, George Loewenstein, and Ted O’Donoghue. 2002. "Time Discounting and Time Preference: A Critical Review." Journal of Economic Literature 40 (2): 351-401.

Fredriksson, Per G., and Eric Neumayer. 2013. "Democracy and Climate Change Policies: Is History Important?" Ecological Economics 95 (November): 11-19. https://doi.org/10.1016/j.ecolecon.2013.08.002.

. 2014. "Corruption and Climate Change Policies: Do the Bad Old Days Matter?" Environmental and Resource Economics, December, 1-19. https://doi.org/10.1007/s10640-014-9869-6.

Gallup. 2009. "Top-Emitting Countries Differ on Climate Change Threat." https://news.gallup.com/poll/124595/Top-Emitting-Countries-Differ-Climate-Change-Threat.aspx\#2 (retrieved May 4, 2018).

Garrett, Geoffrey. 1993. "The Politics of Structural Change Swedish Social Democracy and Thatcherism in Comparative Perspective." Comparative Political Studies 25 (4): 521-47. https://doi.org/10.1177/0010414093025004004.

Gillard, Ross. 2016. "Unravelling the United Kingdom’s Climate Policy Consensus: The Power of Ideas, Discourse and Institutions." Global Environmental Change 40 (September): 26-36. https://doi.org/10.1016/j.gloenvcha.2016.06.012.

González-Ricoy, Iñigo, and Axel Gosseries. 2016. Institutions For Future Generations. Oxford University Press.

Gourevitch, Peter Alexis, and James Shinn. 2005. Political Power and Corporate Control: The New Global Politics of Corporate Governance. Princeton University Press.

Government of Sweden. 2018. "Sweden's Carbon Tax.” http://www.government.se/government-policy/taxes-and-tariffs/swedens-carbon-tax/ (accessed March 6, 2018).

Hall, Peter A., and David W. Soskice. 2001. Varieties of Capitalism: The Institutional Foundations of Comparative Advantage. Oxford: Oxford University Press.

Harrison, Kathryn. 2015. "International Carbon Trade and Domestic Climate Politics." Global Environmental Politics 15 (3): 27-48. https://doi.org/10.1162/GLEP_a_00310.

Harrison, Kathryn, and Lisa McIntosh Sundstrom. 2010. Global Commons, Domestic Decisions: The Comparative Politics of Climate Change. MIT Press.

Hatch, Michael T. 1995. “The Politics of Global Warming in Germany.” Environmental Politics 4 (3): 41540. https://doi.org/10.1080/09644019508414214. 
Hermann, Andrea Tony, Karl Hogl, and Michael Pregernig. 2016. "Science-Policy Interactions in Austrian, Dutch, and Swiss Climate Policy: A Comparative Account." Journal of Environmental Policy \& Planning 0 (0): 1-15. https://doi.org/10.1080/1523908X.2016.1180238.

Hobolt, Sara, James Tilley, and Susan Banducci. 2013. "Clarity of Responsibility: How Government Cohesion Conditions Performance Voting." European Journal of Political Research 52 (2): 164-87. https://doi.org/10.1111/j.1475-6765.2012.02072.x.

Hovi, Jon, Detlef F. Sprinz, and Arild Underdal. 2009. "Implementing Long-Term Climate Policy: Time Inconsistency, Domestic Politics, International Anarchy." Global Environmental Politics 9 (3): 20-39. https://doi.org/10.1162/glep.2009.9.3.20.

Huber, John D., and G. Bingham Powell. 1994. "Congruence Between Citizens and Policymakers in Two Visions of Liberal Democracy.” World Politics 46 (3): 291-326. https://doi.org/10.2307/2950684.

Hughes, Llewelyn, and Johannes Urpelainen. 2015. "Interests, Institutions, and Climate Policy: Explaining the Choice of Policy Instruments for the Energy Sector." Environmental Science \& Policy 54 (December): 52-63. https://doi.org/10.1016/j.envsci.2015.06.014.

International Energy Agency (IEA). 2017. Energy Statistics of OECD Countries. Paris: International Energy Agency.

Iversen, Torben, and David Soskice. 2006. "Electoral Institutions and the Politics of Coalitions: Why Some Democracies Redistribute More than Others." The American Political Science Review 100 (2): $165-81$.

. 2009. "Distribution and Redistribution: The Shadow of the Nineteenth Century." World Politics 61 (03): 438-486. https://doi.org/10.1017/S004388710900015X.

Jacobs, Alan M. 2011. Governing for the Long Term: Democracy and the Politics of Investment. Cambridge: Cambridge University Press. http://ebooks.cambridge.org/ref/id/CBO9780511921766.

_ 2016. "Policy Making for the Long Term in Advanced Democracies." Annual Review of Political Science 19 (1): 433-54. https://doi.org/10.1146/annurev-polisci-110813-034103.

Jacobs, Alan M., and J. Scott Matthews. 2012. "Why Do Citizens Discount the Future? Public Opinion and the Timing of Policy Consequences." British Journal of Political Science 42 (4): 903-35. https://doi.org/10.1017/S0007123412000117.

2017. "Policy Attitudes in Institutional Context: Rules, Uncertainty, and the Mass Politics of Public Investment." American Journal of Political Science 61 (1): 194-207. https://doi.org/10.1111/ajps.12209.

Jacobs, Alan M., and R. Kent Weaver. 2015. "When Policies Undo Themselves: Self-Undermining Feedback as a Source of Policy Change." Governance 28 (4): 441-57. https://doi.org/10.1111/gove.12101.

Jahn, Detlef. 2016. The Politics of Environmental Performance: Institutions and Preferences in Industrialized Democracies. /core/books/politics-of-environmental-perfor-

mance/28AB4A9B9C90DAE039D9204CDC6015CA.

Jotzo, Frank. 2012. “Australia’s Carbon Price.” Nature Climate Change 2, 475-476.

Karapin, Roger. 2016. Political Opportunities for Climate Policy: California, New York, and the Federal Government. Cambridge University Press.

Kasa, Sjur. 2000. "Policy Networks as Barriers to Green Tax Reform: The Case of CO2-taxes in Norway." Environmental Politics 9 (4): 104-22. https://doi.org/10.1080/09644010008414553. 
Katzenstein, Peter J. 1985. Small States in World Markets: Industrial Policy in Europe. Cornell University Press.

Kayser, Mark Andreas, and René Lindstädt. 2015. "A Cross-National Measure of Electoral Competitiveness.” Political Analysis 23 (2): 242-53. https://doi.org/10.1093/pan/mpv001.

Kelsey, Nina. 2018. "Industry Type and Environmental Policy: Industry Characteristics Shape the Potential for Policymaking Success in Energy and the Environment." Business and Politics, 1-28. https://doi.org/10.1017/bap.2018.19.

Kemp, René. 2010. “The Dutch Energy Transition Approach.” International Economics and Economic Policy 7 (2): 291-316. https://doi.org/10.1007/s10368-010-0163-y.

Keohane, Robert O. 2015. “The Global Politics of Climate Change: Challenge for Political Science." PS: Political Science \& Politics 48 (01): 19-26.

Keohane, Robert O., and David G. Victor. 2016. "Cooperation and Discord in Global Climate Policy." Nature Climate Change 6 (6): 570-75. https://doi.org/10.1038/nclimate2937.

LaChappelle, Erick. 2011. "Energy Security and Climate Change Policy in the OECD: Political Economy of Energy Taxation." https://tspace.library.utoronto.ca/bitstream/1807/29780/1/Lachapelle_Erick_201106_PhD_thesis.pdf.

Laswell, Harold D. 1936. "Politics: Who Gets What, When, How.” Cleveland: Meridian Books 1958: 455.

Lehmbruch, Gerhard. 1984. "Concertation and the Structure of Corporatist Networks." http://www.academia.edu/download/23628045/Concertation.pdf.

Levin, Kelly, Benjamin Cashore, Steven Bernstein, and Graeme Auld. 2012. "Overcoming the Tragedy of Super Wicked Problems: Constraining Our Future Selves to Ameliorate Global Climate Change." Policy Sciences 45 (2): 123-52. https://doi.org/10.1007/s11077-012-9151-0.

Lijphart, Arend. 2012. Patterns of Democracy: Government Forms and Performance in Thirty-Six Countries. Yale University Press.

Lindvall, Johannes. 2017. Reform Capacity. Oxford: Oxford University Press.

Lipscy, Phillip Y. 2018. The Institutional Politics of Energy and Climate Change. Book Manuscript. Stanford University, Stanford CA.

Lockwood, Matthew. 2013. "The Political Sustainability of Climate Policy: The Case of the UK Climate Change Act.” Global Environmental Change 23 (5): 1339-48. https:/ /doi.org/10.1016/j.gloenvcha.2013.07.001.

. 2016. "The UK's Levy Control Framework for Renewable Electricity Support: Effects and Significance.” Energy Policy 97 (October): 193-201. https://doi.org/10.1016/j.enpol.2016.07.026.

Mackenzie, Michael K. 2016. "Institutional Design and Sources of Short-Termism.” In Institutional Design and Sources of Short-Termism. Oxford University Press.

MacNeil, Robert. 2015. "Death and Environmental Taxes: Why Market Environmentalism Fails in Liberal Market Economies." Global Environmental Politics 16 (1): 21-37. https://doi.org/10.1162/GLEP_a_00336.

Madden, Nathan J. 2014. "Green Means Stop: Veto Players and Their Impact on Climate-Change Policy Outputs.” Environmental Politics 23 (4): 570-89. https://doi.org/10.1080/09644016.2014.884301.

Martin, Cathie Jo. 2013. "Negotiating Political Agreements." Negotiating Agreement in Politics, 1.

. 2014. "Labour Market Coordination and the Evolution of Tax Regimes." Socio-Economic Review, April, mwu018. https://doi.org/10.1093/ser/mwu018. 
2015. "Negotiation and the Micro-Foundations of Institutional Change." In Cooperation and Conflict the Nordic Way: Work, Welfare, and Institutional Change in Scandinavia. De Gruyter. https://doi.org/10.1515/9783110436891-003.

Martin, Cathie Jo, and Duane Swank. 2012. The Political Construction of Business Interests: Coordination, Growth, and Equality. Cambridge: Cambridge University Press. http://ebooks.cambridge.org/ref/id/CBO9781139088299.

Martin, and Vanberg. 2011. Parliaments and CoalitionsThe Role of Legislative Institutions in Multiparty Governance. Oxford University Press.

Meckling, Jonas, Nina Kelsey, Eric Biber, and John Zysman. 2015. "Winning Coalitions for Climate Policy.” Science 349 (6253): 1170-71. https://doi.org/10.1126/science.aab1336.

Meckling, Jonas, and Jonas Nahm. 2018. "When Do States Disrupt Industries? Electric Cars and the Politics of Innovation.” Review of International Political Economy 25 (4): 505-29. https://doi.org/10.1080/09692290.2018.1434810.

Michaelowa, Axel. 2003. "Germany—a Pioneer on Earthen Feet?" Climate Policy, EU-Implementation Challenges, 3 (1): 31-43. https://doi.org/10.1016/S1469-3062(02)00103-1.

Midttun, Atle, and Oskar Hagen. 1997. "Environmental Policy as Democratic Proclamation and Corporatist Implementation: A Comparative Study of Environmental Taxation in the Electricity Sector in the Nordic Countries as of 1994." Scandinavian Political Studies 20 (3): 285-310. https://doi.org/10.1111/j.1467-9477.1997.tb00196.x.

Mildenberger, Matto. 2018. The Logic of Double Representation in Climate Politics. Book Manuscript. University of California Santa Barbara.

Öberg, PerOla, Torsten Svensson, Peter Munk Christiansen, Asbjørn Sonne Nørgaard, Hilmar Rommetvedt, and Gunnar Thesen. 2011. "Disrupted Exchange and Declining Corporatism: Government Authority and Interest Group Capability in Scandinavia." Government and Opposition 46 (3): 365-91. https://doi.org/10.1111/j.1477-7053.2011.01343.x.

Ozymy, Joshua, and Denis Rey. 2013. "Wild Spaces or Polluted Places: Contentious Policies, Consensus Institutions, and Environmental Performance in Industrialized Democracies." Global Environmental Politics 13 (4): 81-100. https://doi.org/10.1162/GLEP_a_00199.

Pearce, David. 2006. “The Political Economy of an Energy Tax: The United Kingdom's Climate Change Levy.” Energy Economics 28 (2): 149-58. https://doi.org/10.1016/j.eneco.2005.10.001.

Poloni-Staudinger, Lori M. 2008. “Are Consensus Democracies More Environmentally Effective?” Environmental Politics 17 (3): 410-30. https://doi.org/10.1080/09644010802055634.

Powell, G. Bingham. 2000. Elections as Instruments of Democracy: Majoritarian and Proportional Visions. Yale University Press.

Powell, G. Bingham, and Guy D. Whitten. 1993. "A Cross-National Analysis of Economic Voting: Taking Account of the Political Context." American Journal of Political Science 37 (2): 391-414. https://doi.org/10.2307/2111378.

Purdon, Mark. 2015. "Advancing Comparative Climate Change Politics: Theory and Method." Global Environmental Politics 15 (3): 1-26. https://doi.org/10.1162/GLEP_e_00309.

Rabe, Barry G. 2010. "The Aversion to Direct Cost Imposition: Selecting Climate Policy Tools in the United States." Governance 23 (4): 583-608. https:// doi.org/10.1111/j.1468-0491.2010.01499.x.

Rafaty, Ryan. 2018. "Perceptions of Corruption, Political Distrust, and the Weakening of Climate Policy." Global Environmental Politics 18 (3): 106-29. https://doi.org/10.1162/glep_a_00471. 
Renn, Ortwin, and Jonathan Paul Marshall. 2016. "Coal, Nuclear and Renewable Energy Policies in Germany: From the 1950s to the 'Energiewende." Energy Policy 99 (Supplement C): 224-32. https://doi.org/10.1016/j.enpol.2016.05.004.

Rogowski, Ronald, and Mark Andreas Kayser. 2002. "Majoritarian Electoral Systems and Consumer Power: Price-Level Evidence from the OECD Countries." American Journal of Political Science 46 (3): 526-39. https://doi.org/10.2307/3088397.

Rootes, Christopher. 2014. "A Referendum on the Carbon Tax? The 2013 Australian Election, the Greens, and the Environment." Environmental Politics 23 (1): 166-73. https://doi.org/10.1080/09644016.2014.878088.

Schmitter, Philippe C. 1974. "Still the Century of Corporatism?" The Review of Politics 36 (01): 85-131. https://doi.org/10.1017/S0034670500022178.

Scruggs, Lyle. 2003. Sustaining Abundance: Environmental Performance in Industrial Democracies. Cambridge: Cambridge University Press. http://ebooks.cambridge.org/ref/id/CBO9780511615689.

Sprinz, Detlef F. 2014. "Long-Term Policy Problems: Definition, Origin, and Responses.” Predicting the Future in Science, Economics, and Politics, 126.

Steinmo, Sven, Kathleen Thelen, and Frank Longstreth. 1992. Structuring Politics: Historical Institutionalism in Comparative Analysis. Cambridge University Press.

Tobin, Paul. 2017. "Leaders and Laggards: Climate Policy Ambition in Developed States." Global Environmental Politics 17 (4): 28-47. https://doi.org/10.1162/GLEP_a_00433.

Toke, David, and HelleØrsted Nielsen. 2015. "Policy Consultation and Political Styles: Renewable Energy Consultations in the UK and Denmark." British Politics 10 (4): 454-74. https://doi.org/10.1057/bp.2015.38.

Tranter, Bruce, and Kate Booth. 2015. "Scepticism in a Changing Climate: A Cross-National Study." Global Environmental Change 33 (July): 154-64. https://doi.org/10.1016/j.gloenvcha.2015.05.003.

Tvinnereim, Endre. 2013. "Paths towards Large, Unilateral Climate Policies: Policy-Seeking, Attenuated Accountability and Second-Order Government Assertiveness." Journal of Energy \& Natural Resources Law 31: 379.

Union of Concerned Scientists (UCS). "Production Tax Credit for Renewable Energy". Union of Concerned Scientists. http://www.ucsusa.org/clean-energy/increase-renewable-energy/productiontax-credit\#.WabKlLKGOHs (retrieved August 30, 2017).

United Nations (UN). 1992. United Nations Framework Convention on Climate Change. FCCC/INFORMAL/84. https://unfccc.int/resource/docs/convkp/conveng.pdf.

Visser, Jelle. 2015. ICTWSS Data base. version 5.0. Amsterdam: Amsterdam Institute for Ad-vanced Labour Studies AIAS.

Weidner, Helmut, and Lutz Mez. 2008. "German Climate Change Policy A Success Story With Some Flaws." The Journal of Environment \& Development 17 (4): 356-78. https://doi.org/10.1177/1070496508325910.

Wines, Michael. 1993. “Tax’s Demise Illustrates First Rule Of Lobbying: Work, Work, Work.” The New York Times, June 14, 1993, sec. U.S. http://www.nytimes.com/1993/06/14/us/tax-s-demise-illustrates-first-rule-of-lobbying-work-work-work.html.

Wood, Geoffrey, and Stephen Dow. 2011. "What Lessons Have Been Learned in Reforming the Renewables Obligation? An Analysis of Internal and External Failures in UK Renewable Energy Policy." Energy Policy 39 (5): 2228-44. https://doi.org/10.1016/j.enpol.2010.11.012. 


\section{Appendices}

\section{Appendix A1. List of sectors included in shadow carbon price data from Althammer and Hille (2016)}

\begin{tabular}{|c|c|c|}
\hline Sector & $\begin{array}{l}\text { ISIC Rev } 3.1 \\
\text { Classification }\end{array}$ & Coding \\
\hline Agriculture, Hunting, Forestry and Fishing & A to $\mathrm{B}$ & Producer \\
\hline Mining and Quarrying & $\mathrm{C}$ & Producer \\
\hline Food, Beverages and Tobacco & D: 15 to 16 & Producer \\
\hline Textiles and Textile Products & D: 17 to 18 & Producer \\
\hline Leather, Leather and Footwear & $\mathrm{D}: 19$ & Producer \\
\hline Wood and Products of Wood and Cork & D: 20 & Producer \\
\hline Pulp, Paper, Paper, Printing and Publishing & D: 21 to 22 & Producer \\
\hline Coke, Refined Petroleum and Nuclear Fuel & D: 23 & Producer \\
\hline Chemicals and Chemical Products & D: 24 & Producer \\
\hline Rubber and Plastics & $\mathrm{D}: 25$ & Producer \\
\hline Other Non-Metallic Mineral & D: 26 & Producer \\
\hline Basic Metals and Fabricated Metal & D: 27 to 28 & Producer \\
\hline Machinery, Nec & D: 29 & Producer \\
\hline Electrical and Optical Equipment & D: 30 to 33 & Producer \\
\hline Transport Equipment & D: 34 to 35 & Producer \\
\hline Manufacturing, Nec; Recycling & D: 36 to 37 & Producer \\
\hline Electricity, Gas and Water Supply & $\mathrm{E}$ & Producer \\
\hline Construction & $\mathrm{F}$ & Consumer \\
\hline $\begin{array}{l}\text { Sale, Maintenance and Repair of Motor Vehicles and Motorcycles; Re- } \\
\text { tail Sale of Fuel }\end{array}$ & G: 50 & Consumer \\
\hline $\begin{array}{l}\text { Wholesale Trade and Commission Trade, Except of Motor Vehicles } \\
\text { and Motorcycles }\end{array}$ & G: 51 & Consumer \\
\hline $\begin{array}{l}\text { Retail Trade, Except of Motor Vehicles and Motorcycles; Repair of } \\
\text { Household Goods }\end{array}$ & G: 52 & Consumer \\
\hline Hotels and Restaurants & $\mathrm{H}$ & Consumer \\
\hline Inland Transport & I: 60 & Consumer \\
\hline Water Transport & I: 61 & Consumer \\
\hline $\begin{array}{l}\text { Other Supporting and Auxiliary Transport Activities; Activities of } \\
\text { Travel Agencies }\end{array}$ & I: 63 & Consumer \\
\hline Post and Telecommunications & I: 64 & Consumer \\
\hline Financial Intermediation & $\mathrm{J}$ & Consumer \\
\hline Real Estate Activities & K: 70 & Consumer \\
\hline Renting of M\&Eq and Other Business Activities & K: 71 to 74 & Consumer \\
\hline Public Admin and Defence; Compulsory Social Security & $\mathrm{L}$ & Consumer \\
\hline Education & $\mathrm{M}$ & Consumer \\
\hline Health and Social Work & $\mathrm{N}$ & Consumer \\
\hline Other Community, Social and Personal Services & $\mathrm{O}$ & Consumer \\
\hline
\end{tabular}


Appendix A2. Summary statistics

\begin{tabular}{|l|l|c|c|c|c|c|}
\hline \multicolumn{1}{|c|}{ Variable } & \multicolumn{1}{|c|}{ Source } & Obs & Mean & $\begin{array}{c}\text { Std. } \\
\text { Dev. }\end{array}$ & Min & Max \\
\hline Overall climate policy investment & $\begin{array}{l}\text { Althammer and } \\
\text { Hille (2016) }\end{array}$ & 269 & 0.169 & 0.224 & -0.269 & 0.814 \\
\hline Costs for consumers & $\begin{array}{l}\text { Althammer and } \\
\text { Hille (2016) }\end{array}$ & 270 & 0.279 & 0.345 & -0.375 & 1.437 \\
\hline Costs for producers & $\begin{array}{l}\text { Althammer and } \\
\text { Hille (2016) }\end{array}$ & 270 & 0.634 & 0.140 & 0.453 & 0.978 \\
\hline Difference in costs & $\begin{array}{l}\text { Althammer and } \\
\text { Hille (2016) }\end{array}$ & 270 & 0.211 & 0.280 & -0.271 & 1.264 \\
\hline Average electoral disproportionality & Lijphart (2012) & 18 & 6.996 & 5.501 & 1.080 & 19.56 \\
\hline Electoral disproportionality & $\begin{array}{l}\text { Armingeon et } \\
\text { al. (2016) }\end{array}$ & 269 & 7.021 & 5.911 & 0.350 & 24.61 \\
\hline $\begin{array}{l}\text { Routine involvement of employers } \\
\text { and labor unions in policymaking }\end{array}$ & Visser (2015) & 269 & 1 & 0.801 & 0 & 2 \\
\hline $\begin{array}{l}\text { Routine involvement of employers } \\
\text { and labor unions in policymaking }\end{array}$ & $\begin{array}{l}\text { Author's re- } \\
\text { coding }\end{array}$ & 269 & 1.112 & 0.793 & 0 & 2 \\
\hline EU membership & $\begin{array}{l}\text { Armingeon et } \\
\text { al. (2016) }\end{array}$ & 270 & 0.778 & 0.417 & 0 & 1 \\
\hline Institutional constraints & $\begin{array}{l}\text { Armingeon et } \\
\text { al. (2016) }\end{array}$ & 269 & 3.781 & 2.208 & 1 & 10 \\
\hline Green preferences of governments & Jahn (2016) & 269 & 2.779 & 7.072 & -16.794 & 23.152 \\
\hline Fossil fuel production per capita & IEA (2018) & 269 & 2.324 & 3.383 & 0 & 12.885 \\
\hline Real GDP growth rate & $\begin{array}{l}\text { Armingeon et } \\
\text { al. (2016) }\end{array}$ & 269 & 2.385 & 2.594 & -8.270 & 11.27 \\
\hline $\begin{array}{l}\text { Consensus democracy (Lijphart's first } \\
\text { dimension) (1981-2010) }\end{array}$ & Lijphart (2012) & 270 & 0.202 & 0.912 & -1.480 & 1.480 \\
\hline Left-right position of government & Jahn (2016) & 269 & 2.293 & 5.220 & -12.788 & 21.497 \\
\hline Unemployment rate & $\begin{array}{l}\text { Armingeon et } \\
\text { al. (2016) }\end{array}$ & 269 & 7.438 & 2.849 & 3.100 & 20.700 \\
\hline GDP per capita & OECD (2018) & 269 & 3.091 & 0.533 & 1.810 & 4.535 \\
\hline $\begin{array}{l}\text { Carbon intensity of total primary en- } \\
\text { ergy supply (TPES) }\end{array}$ & IEA (2018) & 269 & 54.655 & 13.064 & 20.680 & 80.600 \\
\hline
\end{tabular}




\section{Appendix A3: Electoral rules and climate policy investment: OLS models}

I use OLS models test the robustness of the relationship between electoral rules and climate policy investment. Because electoral disproportionality is only substantively meaningful across countries, I take the average of each control variable over the sample period (1995-2009). ${ }^{36}$ The drawback of this approach is that it leaves only 18 observations (one for each country), which limits the model's degrees of freedom and statistical power. I therefore choose a parsimonious and theoretically motivated set of controls (described in the main text). Table A1 presents the results. Figure A1 shows the differential effect of electoral rules on policy costs for consumers versus producers.

Table A1. Electoral rules and climate policy investment: Cross-sectional OLS models

\begin{tabular}{lcccc}
\hline & $\begin{array}{c}(1) \\
\text { Overall cli- } \\
\text { mate policy } \\
\text { investment }\end{array}$ & $\begin{array}{c}(2) \\
\text { Costs for } \\
\text { consumers }\end{array}$ & $\begin{array}{c}(3) \\
\text { Costs for } \\
\text { producers }\end{array}$ & $\begin{array}{c}(4) \\
\text { Difference } \\
\text { in costs }\end{array}$ \\
\hline Electoral disproportionality & $-0.0160^{* * *}$ & $-0.0253^{* * *}$ & $-0.00715^{* *}$ & $-0.0182^{* *}$ \\
EU Membership & $(0.00448)$ & $(0.00807)$ & $(0.00310)$ & $(0.00812)$ \\
& 0.0297 & 0.174 & $-0.107^{*}$ & 0.282 \\
Institutional constraints & $(0.0980)$ & $(0.173)$ & $(0.0537)$ & $(0.160)$ \\
& -0.0261 & -0.0350 & -0.0176 & -0.0174 \\
Green policy preferences & $(0.0189)$ & $(0.0333)$ & $(0.00990)$ & $(0.0304)$ \\
& 0.00759 & $0.0153^{*}$ & 0.000305 & $0.0150^{*}$ \\
Real GDP growth & $(0.00478)$ & $(0.00778)$ & $(0.00325)$ & $(0.00694)$ \\
Fossil fuel production & -0.0738 & $-0.126^{*}$ & -0.0240 & $-0.102^{*}$ \\
Constant & $(0.0500)$ & $(0.0687)$ & $(0.0408)$ & $(0.0517)$ \\
& -0.00877 & 0.00728 & $-0.0239^{* *}$ & 0.0312 \\
\hline R & $(0.0162)$ & $(0.0274)$ & $(0.00834)$ & $(0.0235)$ \\
$N$ & $0.533^{* * *}$ & $0.693^{* *}$ & $0.380^{* * *}$ & 0.313 \\
\hline Robust standard errors in parentheses. ${ }^{*} p<0.10,{ }^{* *} p<0.05,{ }^{* * *} p<0.01$ & $(0.248)$ \\
\hline
\end{tabular}

\footnotetext{
${ }^{36}$ Japan and Italy changed electoral rules during the sample period. In this case of Japan, it occurred in 1996. In the case Italy, it was 2005 . Having only two countries with few years either before or after the change prevents any meaningful estimate of its effect.
} 
Figure A1. Electoral rules and distribution of policy costs

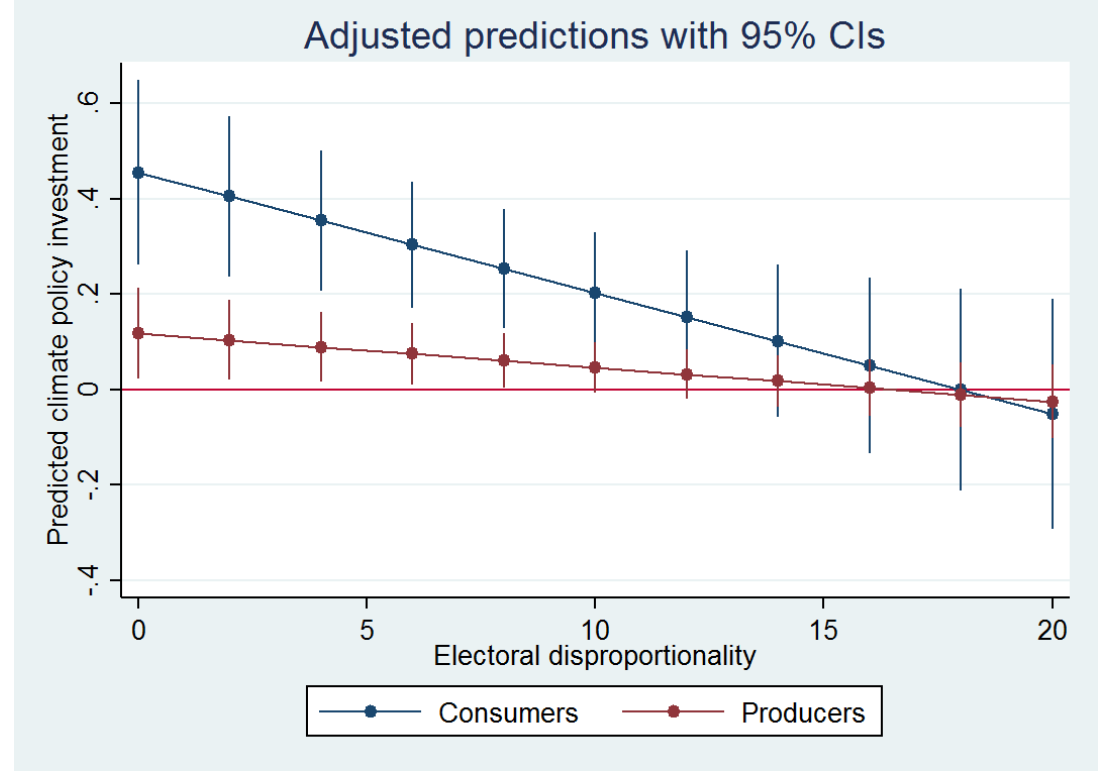




\section{Appendix A4. Concertation and climate policy investment: Robustness tests}

Table A2. Concertation and climate policy investment: Hybrid models with additional controls

\begin{tabular}{|c|c|c|c|c|}
\hline & $\begin{array}{l}\text { (1) } \\
\text { Overall cli- } \\
\text { mate policy } \\
\text { investment }\end{array}$ & $\begin{array}{c}\text { (2) } \\
\text { Costs for } \\
\text { consumers }\end{array}$ & $\begin{array}{l}\text { (3) } \\
\text { Costs for } \\
\text { producers }\end{array}$ & $\begin{array}{c}(4) \\
\text { Difference } \\
\text { in costs }\end{array}$ \\
\hline \multicolumn{5}{|l|}{ Between-country effects } \\
\hline \multirow[t]{2}{*}{ Concertation } & $0.0940^{* *}$ & $0.184^{* *}$ & 0.00905 & $0.176^{* * *}$ \\
\hline & $(0.0470)$ & $(0.0737)$ & $(0.0373)$ & $(0.0677)$ \\
\hline \multirow[t]{2}{*}{ EU Membership } & 0.128 & $0.389^{* *}$ & $-0.118^{* *}$ & $0.508^{* * *}$ \\
\hline & $(0.103)$ & $(0.175)$ & $(0.0560)$ & $(0.152)$ \\
\hline \multirow[t]{2}{*}{ Institutional constraints } & -0.0318 & -0.0251 & -0.0381 & 0.0131 \\
\hline & $(0.0202)$ & $(0.0221)$ & $(0.0251)$ & $(0.0248)$ \\
\hline \multirow[t]{2}{*}{ Green policy preferences } & $0.00818^{* * *}$ & $0.0158^{* * *}$ & 0.00103 & $0.0147^{* * *}$ \\
\hline & $(0.00303)$ & $(0.00516)$ & $(0.00287)$ & $(0.00566)$ \\
\hline \multirow[t]{2}{*}{ Fossil fuel production } & -0.0136 & 0.00131 & $-0.0277^{* * *}$ & 0.0290 \\
\hline & $(0.0137)$ & $(0.0219)$ & $(0.00954)$ & $(0.0192)$ \\
\hline \multirow[t]{2}{*}{ Real GDP growth } & $-0.0916^{* * *}$ & $-0.133^{* * *}$ & -0.0525 & $-0.0804^{* *}$ \\
\hline & $(0.0255)$ & $(0.0220)$ & $(0.0385)$ & $(0.0374)$ \\
\hline \multirow[t]{2}{*}{ Left-right position of gov } & 0.00348 & 0.0166 & -0.00884 & $0.0254^{*}$ \\
\hline & $(0.00697)$ & $(0.0119)$ & $(0.00776)$ & $(0.0143)$ \\
\hline \multirow[t]{2}{*}{ Unemployment rate } & -0.00320 & -0.0211 & 0.0136 & $-0.0348^{*}$ \\
\hline & $(0.0151)$ & $(0.0141)$ & $(0.0209)$ & $(0.0193)$ \\
\hline \multirow[t]{2}{*}{ GDP per capita } & 0.136 & $0.164^{* *}$ & 0.108 & 0.0552 \\
\hline & $(0.0981)$ & $(0.0784)$ & $(0.141)$ & $(0.121)$ \\
\hline \multirow[t]{2}{*}{ Carbon intensity } & $0.00553^{* *}$ & $0.00684^{* *}$ & $0.00428^{*}$ & 0.00255 \\
\hline & $(0.00233)$ & $(0.00325)$ & $(0.00228)$ & $(0.00308)$ \\
\hline \multicolumn{5}{|l|}{ Within-country effects } \\
\hline \multirow[t]{2}{*}{ Concertation } & $0.0439^{*}$ & $0.0736^{* *}$ & 0.0161 & $0.0576^{* * *}$ \\
\hline & $(0.0229)$ & $(0.0315)$ & $(0.0163)$ & $(0.0198)$ \\
\hline \multirow[t]{2}{*}{ Green policy preferences } & 0.00263 & 0.00370 & 0.00165 & 0.00208 \\
\hline & $(0.00272)$ & $(0.00360)$ & $(0.00229)$ & $(0.00254)$ \\
\hline \multirow[t]{2}{*}{ Fossil fuel production } & 0.00458 & 0.0152 & -0.00555 & 0.0206 \\
\hline & $(0.0115)$ & $(0.0159)$ & $(0.0109)$ & $(0.0143)$ \\
\hline \multirow[t]{2}{*}{ Real GDP growth } & -0.00537 & -0.00900 & -0.00197 & -0.00707 \\
\hline & $(0.00483)$ & $(0.00731)$ & $(0.00322)$ & $(0.00565)$ \\
\hline \multirow[t]{2}{*}{ Left-right position of gov } & -0.00133 & -0.00269 & -0.0000560 & -0.00265 \\
\hline & $(0.00335)$ & $(0.00390)$ & $(0.00318)$ & $(0.00236)$ \\
\hline \multirow[t]{2}{*}{ Unemployment rate } & -0.00385 & 0.00305 & -0.0104 & $0.0134^{* *}$ \\
\hline & (0.00938) & $(0.00951)$ & $(0.0104)$ & $(0.00676)$ \\
\hline \multirow[t]{2}{*}{ GDP per capita } & -0.0174 & 0.0380 & -0.0708 & 0.107 \\
\hline & $(0.139)$ & $(0.155)$ & $(0.139)$ & $(0.0931)$ \\
\hline \multirow[t]{2}{*}{ Carbon intensity } & -0.00552 & -0.00481 & -0.00618 & 0.00138 \\
\hline & $(0.00430)$ & $(0.00543)$ & $(0.00386)$ & $(0.00373)$ \\
\hline Year FE & Yes & Yes & Yes & Yes \\
\hline $\mathrm{R}^{2}-$ within & 0.386 & 0.399 & 0.330 & 0.340 \\
\hline $\mathrm{R}^{2}$ - between & 0.832 & 0.860 & 0.655 & 0.816 \\
\hline $\mathrm{R}^{2}$ - overall & 0.765 & 0.809 & 0.584 & 0.787 \\
\hline Countries & 18 & 18 & 18 & 18 \\
\hline$N$ & 268 & 268 & 268 & 268 \\
\hline
\end{tabular}


Table A3. Concertation and climate policy investment: OLS models

\begin{tabular}{lcccc}
\hline & $\begin{array}{c}(1) \\
\text { Overall climate pol- } \\
\text { icy investment }\end{array}$ & $\begin{array}{c}(2) \\
\text { Costs for } \\
\text { consumers }\end{array}$ & $\begin{array}{c}(3) \\
\text { Costs for } \\
\text { producers }\end{array}$ & $\begin{array}{c}(4) \\
\text { Difference in } \\
\text { costs }\end{array}$ \\
\hline Concertation & $0.141^{*}$ & $0.264^{* *}$ & 0.0268 & $0.238^{* *}$ \\
EU Membership & $(0.0669)$ & $(0.108)$ & $(0.0436)$ & $(0.0935)$ \\
Institutional constraints & 0.107 & 0.308 & -0.0829 & $0.391^{* *}$ \\
& $(0.114)$ & $(0.188)$ & $(0.0634)$ & $(0.156)$ \\
Green policy preferences & -0.0207 & -0.0202 & -0.0211 & 0.000940 \\
& $(0.0185)$ & $(0.0293)$ & $(0.0133)$ & $(0.0259)$ \\
Fossil fuel production & 0.00809 & $0.0174^{*}$ & -0.000645 & $0.0180^{* *}$ \\
& $(0.00582)$ & $(0.00899)$ & $(0.00358)$ & $(0.00696)$ \\
Real GDP growth & 0.00367 & 0.0312 & $-0.0221^{*}$ & $0.0533^{*}$ \\
& $(0.0202)$ & $(0.0338)$ & $(0.0100)$ & $(0.0280)$ \\
Constant & -0.0709 & $-0.122^{* *}$ & -0.0218 & $-0.100^{* *}$ \\
& $(0.0425)$ & $(0.0510)$ & $(0.0401)$ & $(0.0354)$ \\
\hline R & 0.147 & -0.00796 & 0.288 & -0.295 \\
$N$ & $(0.229)$ & $(0.335)$ & $(0.171)$ & $(0.266)$ \\
\hline
\end{tabular}

Robust standard errors in parentheses. ${ }^{*} p<0.10,{ }^{* *} p<0.05,{ }^{* * *} p<0.01$

Table A4. Concertation and climate policy investment: Fixed effects models

\begin{tabular}{lcccc}
\hline & $\begin{array}{c}(1) \\
\text { Overall climate } \\
\text { policy invest- } \\
\text { ment }\end{array}$ & $\begin{array}{c}(2) \\
\text { Costs for } \\
\text { consumers }\end{array}$ & $\begin{array}{c}(3) \\
\text { Costs for } \\
\text { producers }\end{array}$ & $\begin{array}{c}\text { Difference in } \\
\text { costs }\end{array}$ \\
\hline Concertation (t-1) & $0.0348^{*}$ & $0.0582^{* *}$ & 0.0188 & $0.0395^{*}$ \\
Green policy preferences (t-1) & $(0.0177)$ & $(0.0270)$ & $(0.0133)$ & $(0.0226)$ \\
& 0.00198 & 0.00184 & 0.00212 & -0.000285 \\
Fossil fuel production (t-1) & $(0.00177)$ & $(0.00200)$ & $(0.00184)$ & $(0.00156)$ \\
& 0.00493 & 0.0121 & -0.00231 & 0.0144 \\
Real GDP growth (t-1) & $(0.0144)$ & $(0.0190)$ & $(0.0118)$ & $(0.0127)$ \\
& -0.00393 & -0.0106 & 0.00216 & -0.0128 \\
\hline Country FE & $(0.00578)$ & $(0.00891)$ & $(0.00426)$ & $(0.00778)$ \\
Year FE & Yes & Yes & Yes & Yes \\
$\mathrm{R}^{2}-$ within & Yes & Yes & Yes & Yes \\
$\mathrm{R}^{2}-$ between & 0.351 & 0.366 & 0.267 & 0.263 \\
$\mathrm{R}^{2}-$ overall & 0.291 & 0.227 & 0.267 & 0.101 \\
Countries & 0.179 & 0.167 & 0.198 & 0.102 \\
$N$ & 18 & 18 & 18 & 18 \\
\hline Robust standard errors in parentheses clustered at the country level. ${ }^{*} p<0.10,{ }^{* *} p<0.05,{ }^{* * *} p<0.01$
\end{tabular}




\section{Appendix A5. Concertation and costs for producers}

Figure A2. Concertation and costs for producers (avg 1995-2009)

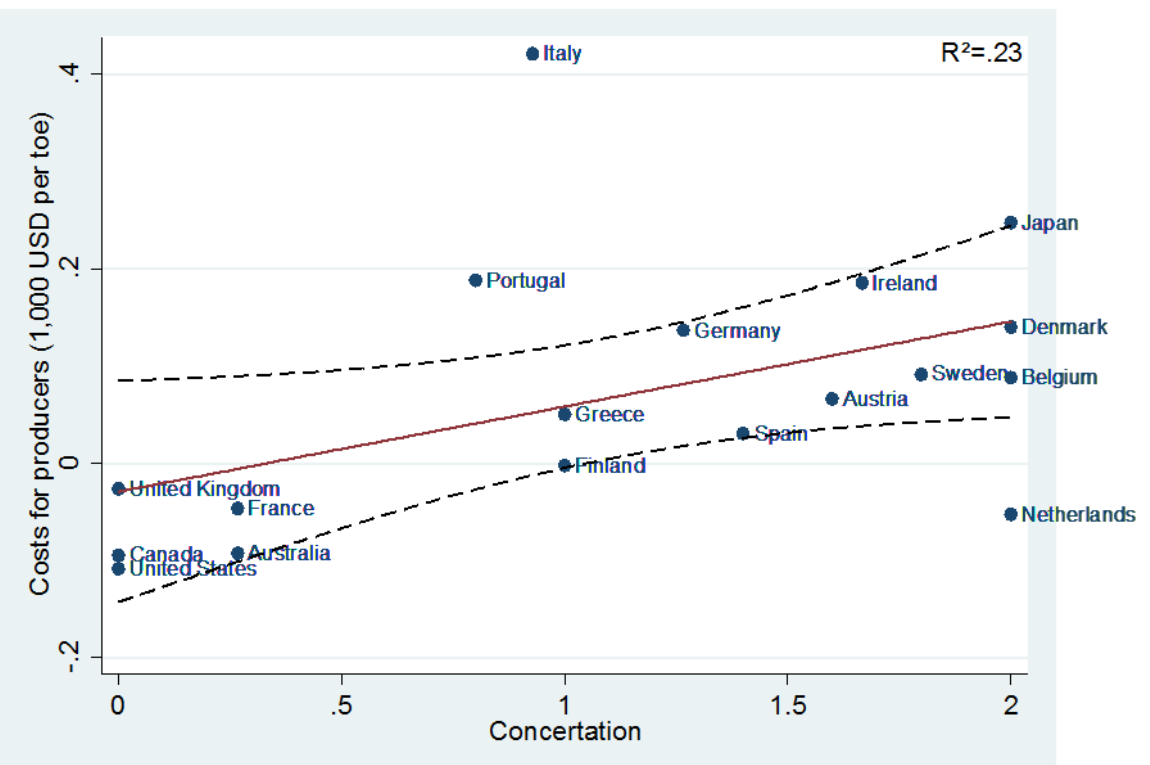




\section{Appendix A6: Institutional complementarities and climate policy investment}

Table A5. Institutional complementarities and climate policy investment: Cross-sectional OLS models

\begin{tabular}{|c|c|c|c|c|}
\hline & $\begin{array}{l}\text { (1) } \\
\text { Overall cli- } \\
\text { mate policy } \\
\text { investment }\end{array}$ & $\begin{array}{c}(2) \\
\text { Costs for } \\
\text { consumers }\end{array}$ & $\begin{array}{l}(3) \\
\text { Costs for } \\
\text { produc- } \\
\text { ers }\end{array}$ & $\begin{array}{c}\text { (4) } \\
\text { Difference } \\
\text { in costs }\end{array}$ \\
\hline First principal component & $\begin{array}{l}0.0842^{* *} \\
(0.0331)\end{array}$ & $\begin{array}{c}0.151^{* *} \\
(0.0582)\end{array}$ & $\begin{array}{c}0.0218 \\
(0.0205)\end{array}$ & $\begin{array}{c}0.129^{* *} \\
(0.0553)\end{array}$ \\
\hline EU Membership & $\begin{array}{c}0.0618 \\
(0.0947)\end{array}$ & $\begin{array}{c}0.224 \\
(0.160)\end{array}$ & $\begin{array}{l}-0.0920 \\
(0.0602)\end{array}$ & $\begin{array}{c}0.316^{*} \\
(0.146)\end{array}$ \\
\hline Institutional constraints & $\begin{array}{l}-0.0225 \\
(0.0175)\end{array}$ & $\begin{array}{l}-0.0250 \\
(0.0289)\end{array}$ & $\begin{array}{l}-0.0200 \\
(0.0113)\end{array}$ & $\begin{array}{r}-0.00507 \\
(0.0257)\end{array}$ \\
\hline Green policy preferences & 0.00833 & $0.0175^{*}$ & $\begin{array}{c}- \\
0.000264 \\
(0.00345)\end{array}$ & $0.0177^{* *}$ \\
\hline Real GDP growth & $\begin{array}{l}-0.0714 \\
(0.0468)\end{array}$ & $\begin{array}{l}-0.123^{*} \\
(0.0603)\end{array}$ & $\begin{array}{l}-0.0221 \\
(0.0406)\end{array}$ & $\begin{array}{l}-0.101^{* *} \\
(0.0424)\end{array}$ \\
\hline Fossil fuel production & $\begin{array}{r}-0.00286 \\
(0.0172)\end{array}$ & $\begin{array}{c}0.0183 \\
(0.0285)\end{array}$ & $\begin{array}{l}-0.0228^{* *} \\
(0.00890)\end{array}$ & $\begin{array}{c}0.0411 \\
(0.0236)\end{array}$ \\
\hline Constant & $\begin{array}{l}0.354^{* *} \\
(0.144)\end{array}$ & $\begin{array}{c}0.388 \\
(0.220) \\
\end{array}$ & $\begin{array}{l}0.320^{* *} \\
(0.105) \\
\end{array}$ & $\begin{array}{l}0.0685 \\
(0.184) \\
\end{array}$ \\
\hline $\mathrm{R}^{2}$ & 0.720 & 0.731 & 0.512 & 0.642 \\
\hline$N$ & 18 & 18 & 18 & 18 \\
\hline
\end{tabular}




\section{Appendix A7. Consensus democracy and long-term climate policy investment}

Figure A3. Consensus democracy and long-term climate policy investment

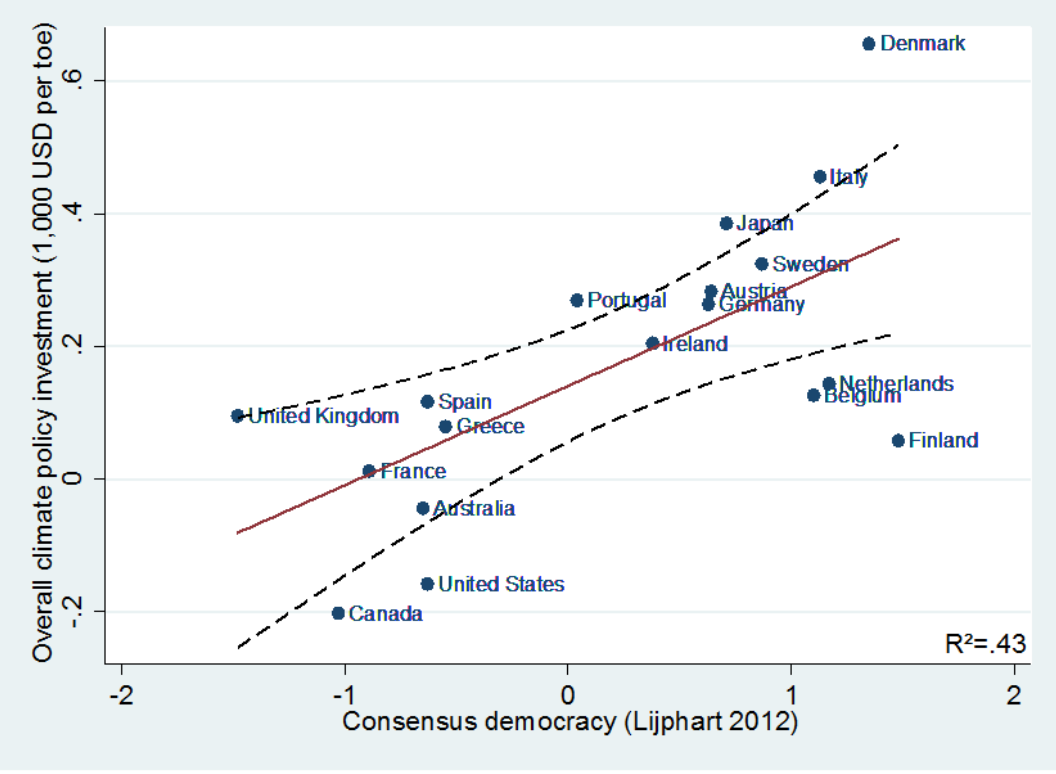

Table A6. Consensus democracy and long-term climate policy investment: Cross-sectional models

\begin{tabular}{lcccc}
\hline & $\begin{array}{c}(1) \\
\text { Overall cli- } \\
\text { mate policy } \\
\text { investment }\end{array}$ & $\begin{array}{c}(2) \\
\text { Costs for } \\
\text { consumers }\end{array}$ & $\begin{array}{c}(3) \\
\text { Costs for } \\
\text { producers }\end{array}$ & $\begin{array}{c}\text { Difference } \\
\text { in costs }\end{array}$ \\
\hline Consensus democracy & $0.110^{*}$ & $0.180^{* *}$ & 0.0427 & $0.137^{*}$ \\
EU Membership & $(0.0499)$ & $(0.0798)$ & $(0.0332)$ & $(0.0688)$ \\
& 0.105 & 0.296 & -0.0758 & $0.372^{* *}$ \\
Institutional constraints & $(0.107)$ & $(0.179)$ & $(0.0670)$ & $(0.159)$ \\
Green policy preferences & -0.0200 & -0.0241 & -0.0163 & -0.00778 \\
& $(0.0149)$ & $(0.0255)$ & $(0.0101)$ & $(0.0241)$ \\
Fossil fuel production & $0.0114^{* *}$ & $0.0218^{* *}$ & 0.00156 & $0.0203^{* *}$ \\
& $(0.00476)$ & $(0.00786)$ & $(0.00350)$ & $(0.00740)$ \\
Real GDP growth & -0.0000607 & 0.0217 & $-0.0206^{* *}$ & 0.0423 \\
& $(0.0175)$ & $(0.0295)$ & $(0.00906)$ & $(0.0253)$ \\
Constant & -0.0587 & -0.101 & -0.0177 & $-0.0836^{*}$ \\
& $(0.0427)$ & $(0.0566)$ & $(0.0379)$ & $(0.0440)$ \\
\hline $\mathrm{R}^{2}$ & 0.250 & 0.233 & $0.266^{* *}$ & -0.0324 \\
$N$ & $(0.149)$ & $(0.237)$ & $(0.0913)$ & $(0.193)$ \\
\hline Robstand & 0.715 & 0.695 & 0.539 & 0.571 \\
& 18 & 18 & 18 & 18 \\
\hline
\end{tabular}

Robust standard errors in parentheses. ${ }^{*} p<0.10,{ }^{* *} p<0.05,{ }^{* * *} p<0.01$ 


\section{Appendix A8. Public opinion and climate policy investment}

The series of plots below compare three different measures of public opinion with overall climate

policy investment. The measure "Environmental concern" is a score calculated by Franzen and $\operatorname{Vogl}$ (2013) based on responses to environmental-related question in three waves of International Social Survey Programme (ISSP) surveys: 1993, 2000, and 2010. The measure "Willing to pay higher taxes to protect the environment" is taken from ISSP data and averaged across three waves: 1993, 2000, and 2010. The measure "Climate change is a personal threat" is taken from a 2007-08 Gallup survey data (Gallup 2009).

The figures provide little evidence of a cross-national relationship between public opinion and climate change policy. Indeed, in Figures A5 and A6 the relationship runs counter to expectations.

Figure A4. Environmental concern and overall climate policy investment (with 95\% CIs)

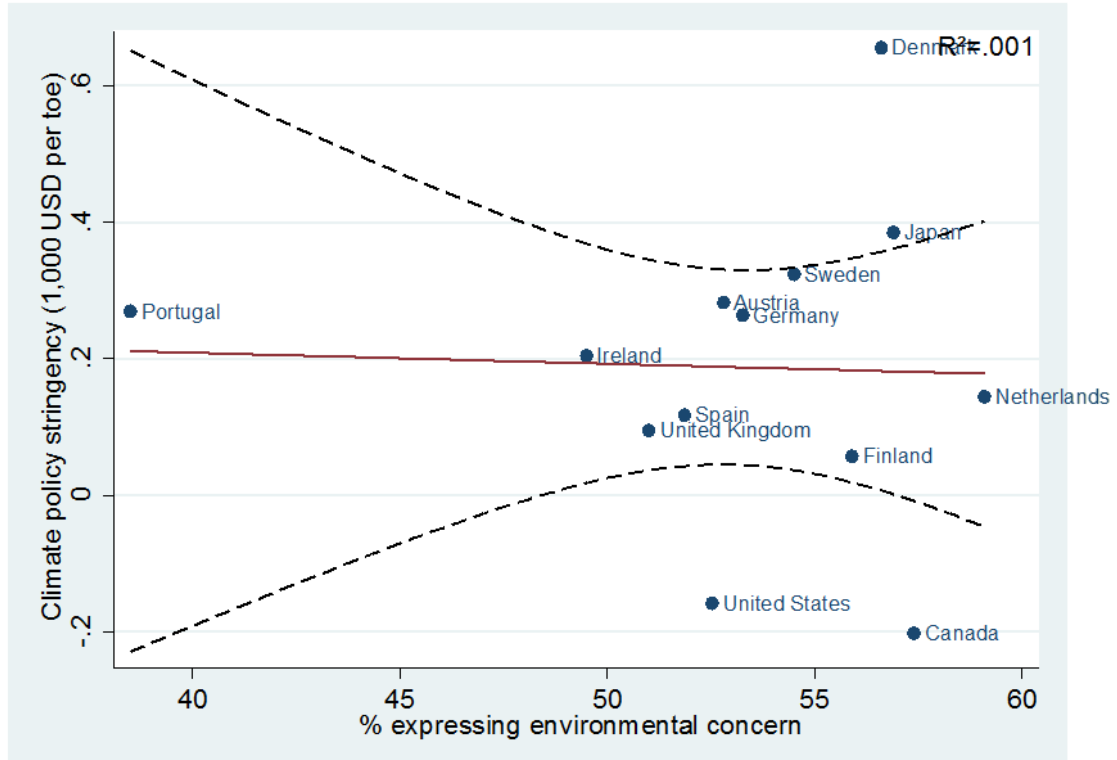


Figure A5. Willingness to pay and overall climate policy investment (with 95\% CIs)

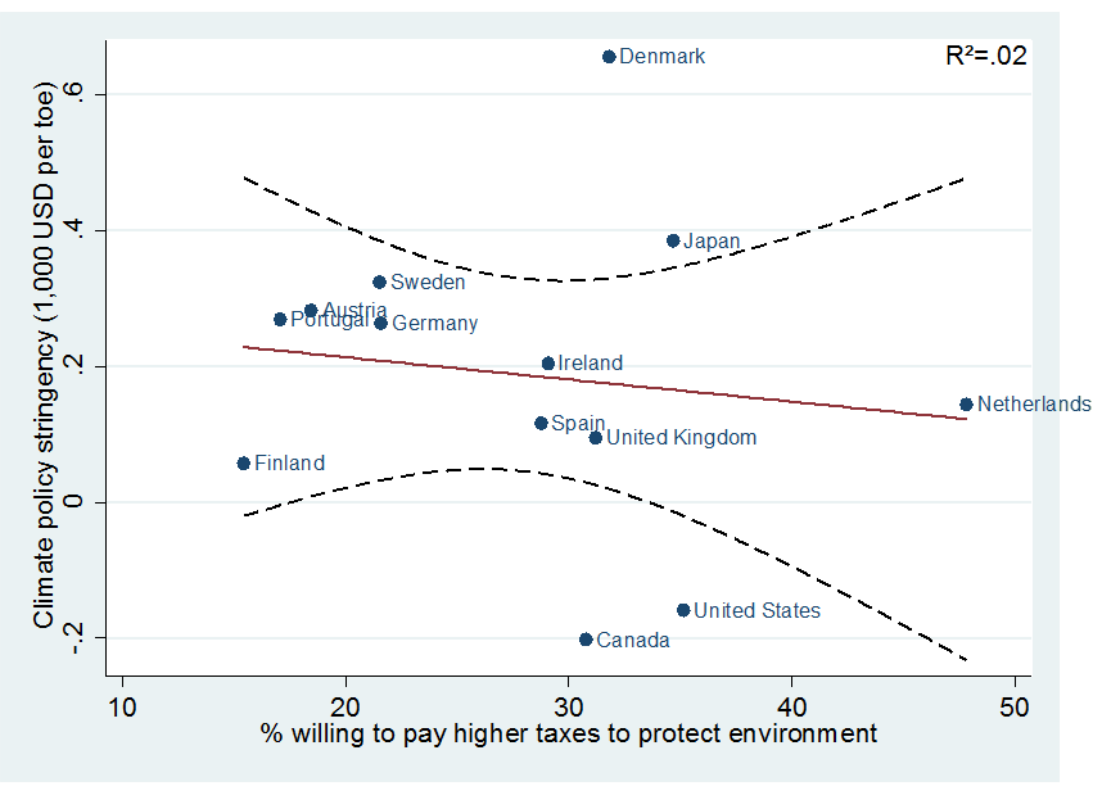

Figure A6. Personal threat and overall climate policy investment (with 95\% CIs)

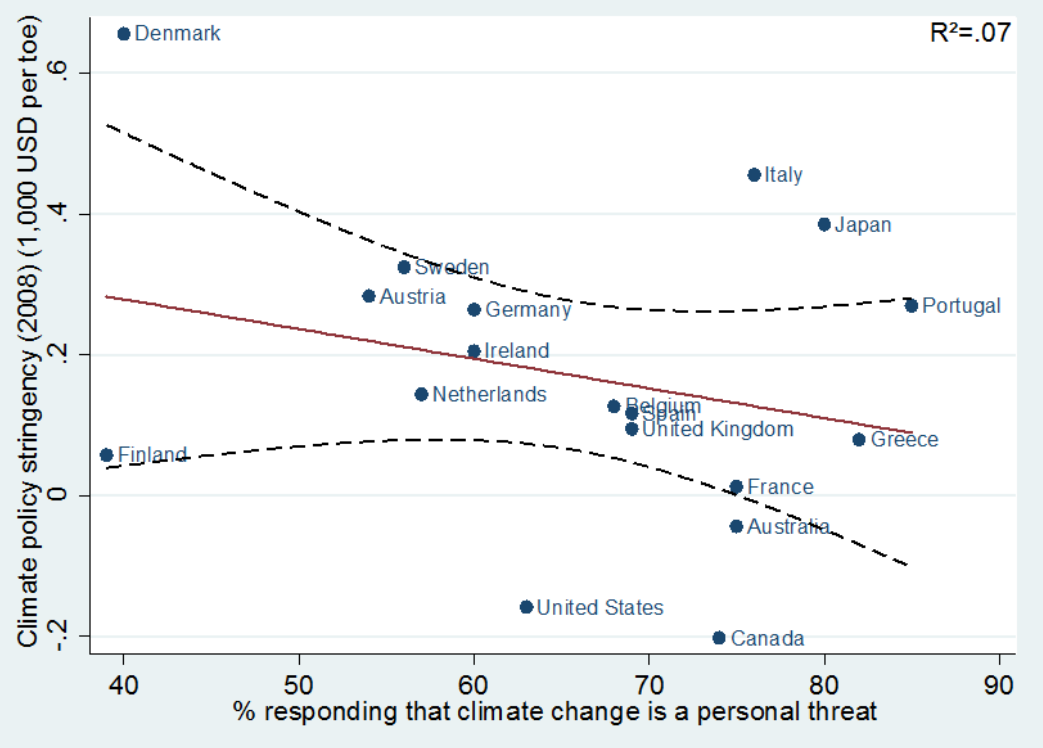

